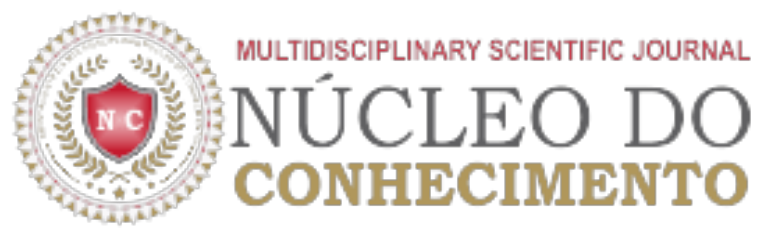

\section{Condições Inseguras em Instalações de Traves para Futsal e Tabelas de Basquetebol}

\author{
CHERVENKO, Valmir ${ }^{[1]}$
}

CHERVENKO, Valmir. Condições Inseguras em Instalações de Traves para Futsal e Tabelas de Basquetebol. Revista Científica Multidisciplinar Núcleo do Conhecimento. Edição 05. Ano 02, Vol. 01. pp 146-186, Julho de 2017. ISSN:2448-0959

\section{Resumo}

Este trabalho busca mostrar as diversas condições inseguras em instalações e equipamentos desportivos ocasionadas pela falta de fiscalização e normas adequadas, bem como, alertar sobre a quantidade de acidentes com vítimas fatais ou portadoras de lesões de diversos níveis de gravidade ocasionados por tais condições. Como fator de condição insegura discorre-se aqui sobre a fixação de traves e tabelas de basquetebol em quadras esportivas de escolas municipais, estaduais, federais e privadas. Embora o número de acidentes e óbitos pertinentes ao esporte seja entendido pela sociedade como um fator inerente à prática esportiva ou como mera fatalidade, verifica-se que estes ocorrem pelas condições inseguras provocadas pela inexistência de normas técnicas, que orientem engenheiros e arquitetos quanto à instalação segura dos equipamentos. A abordagem deste tema se justifica pela possibilidade de redução de acidentes, de auxílios doença e de gastos com atendimentos médicos, a partir da revisão de recintos esportivos e quadras poliesportivas localizadas em condomínios, escolas, clubes e parques públicos. Embora todos os tipos de quadras tenham extrema importância para este estudo, por questões de direcionamento, este trabalho buscará enfatizar apenas as quadras de escolas para formação de dados estatísticos e estimativa para outros setores encontrados.

Palavras-Chave: Traves de Futsal, Tabela de Basquetebol, Acidentes com Traves, Acidentes com Tabelas de Basquetebol, Engenharia ou Arquitetura Esportiva, Quadras Poliesportivas.

\section{INTRODUÇÃO}

O futebol é componente da história cultural do brasileiro, sendo parte da rotina diária ou semanal de muitos deles. Este esporte iniciou-se no Brasil em campinhos de terra onde, nas regiões mais desenvolvidas, tornaram-se quadras de grama sintética ou assoalho. Por ser o futebol uma atividade tão 
enraizada na formação do brasileiro é que se devem buscar meios de evitar que a falta de cuidados específicos venha a gerar sequelas irremediáveis.

A falta de normas técnicas e de certificação de equipamentos esportivos tem gerado um ambiente favorável a um número imenso de traumas, contusões e, não raro, mortes a seus usuários, o que torna importante o levantamento dos problemas relativos a estes equipamentos e o estabelecimento de parâmetros de confecção e difusão da ideia de existência de norma e legislação específicas, que exijam condições mínimas de segurança para a boa utilização desses espaços.

Assim, este trabalho tem por objetivo prestar esclarecimentos às autoridades competentes quanto à criação de mecanismos para a solução de diversos problemas que serão apontados, todos provenientes da falta de segurança para a prática de atividades esportivas em quadras construídas sem critérios de engenharia de segurança, que colocam usuários em condições extremas de risco de vida por acidentes involuntários.

Busca-se, ainda, mostrar as condições inseguras observadas em vistorias in-loco, concernentes a traves de futebol e tabelas de basquetebol instaladas sem critérios mínimos de segurança ou com falta de manutenção preventiva e corretiva, além de demonstrar, por meio de dados obtidos em normas internacionais de fixação de traves e tabelas, croquis ou fotos orientativas sobre formas seguras de fixação desses elementos nas quadras esportivas.

\section{CONDIÇÕES INSEGURAS E ACIDENTES}

Segundo o Ministério da Saúde (MS), acidente define-se como o evento não intencional e evitável, causador de lesões físicas e/ou emocionais no âmbito doméstico ou em outros ambientes sociais, como o do trabalho, trânsito, da escola, de esportes e de lazer.

Conforme estudo efetuado pela Associação para a Promoção da Segurança Infantil de Portugal (APSI), as traves das quadras das escolas continuam a ser uma ameaça. Uma em cada oito balizas (traves) fixas de escolas ou de espaços de lazer públicos, testadas pela APSI, tombaram perante o teste e $82 \%$ das balizas, encontradas em repouso, estavam soltas. O estudo deste trabalho demonstrou, ainda, que no Brasil a maioria das tabelas de basquetebol é antiga e que precisam receber o dispositivo de segurança para que toda sobrecarga no aro seja contida por sistema de fixação no piso, na parte central e na parte posterior da base.

Harada (2003) faz referência a uma pesquisa realizada nos Estados Unidos, que aponta que, a cada ano, 3,7 milhões de crianças sofrem acidentes nas escolas. Segundo outra investigação (Souza e Tibeau, 2008) realizada em 20 escolas participantes do projeto Unimed Vida, na cidade de Blumenau no ano de 2000, dos 287 acidentes registrados no período de um ano, 117 (41\%) deles ocorreram em quadra esportiva. A maior incidência de acidentes $(55 \%)$ aconteceu durante as aulas.

Collucci (2006) apresenta dados de uma pesquisa feita em 23 escolas públicas e privadas de São Paulo, onde $78 \%$ de crianças vítimas de acidentes se machucaram em quadras esportivas na presença de adultos.

No Brasil, pouquíssimos são os dados estatísticos específicos para acidentes e óbitos em quadras esportivas, porém, pesquisas efetuadas em artigos jornalísticos revelam um número relevante. 


\section{CONCEITOS E DEFINIÇÕES}

\subsection{Traves de futsal}

Segundo a Confederação Brasileira de Futebol de Salão (CBFS) as Metas ou traves, devem ser, "de preferência", fixadas no solo, fato que se equivoca em relação à segurança. Já para a Liga Nacional de Futebol de Salão (LNFS), "as traves poderão ser fixas ou móveis, com peso extra na base para que esta não venha a se deslocar ou tombar”, o que leva a uma segurança parcial. Para a Federação Internacional de Futebol Associados (FIFA), em seu regulamento de 2014/2015, "as metas devem ter um sistema de estabilização que as impeçam de tombar. Traves móveis só podem ser utilizadas se satisfizerem essa exigência". Esta colocação não dá importância devida à Engenharia de Segurança, dando margem para o descaso na definição do sistema.

Considera-se, neste estudo, que as traves deverão ser instaladas visando sua fixação não permanente, ou seja, devem estar soltas para que o indivíduo não receba o impacto total no caso de choque com a estrutura, como preconiza a FIFA, no entanto, a mesma deve estar fixada por sistema tal que, não venha a pendular e tombar sobre o praticante e, quando utilizados diferentes metais entre trave e sistema de fixação, estes deverão ter seus potenciais de corrosão o mais próximo da tabela galvânica, a fim de se evitar reação química, denominada de "Pilha Eletrolítica", que causa a corrosão galvânica do metal menos nobre.

\subsection{Tabelas de basquetebol}

Conforme preconiza a Federação Internacional de Basquetebol (FIBA), para equipamento Tipo-1 e 2, "a estrutura de suporte da tabela deverá ser presa no solo para impedir qualquer movimento. Se não for possível prendê-la no solo, um peso adicional no suporte da base da tabela deverá ser usado para impedir qualquer movimento. " Esta afirmação não dá importância devida à Engenharia de Segurança, dando margem para o descaso na definição do sistema. Para a Liga Nacional de Basquetebol (LNB), no caso de equipamento Tipo-1 e 2 (Móvel), e Tipo 6 e 7 (Fixas ao chão), "a estrutura das tabelas deverá ser móvel ou fixada no chão”, o que provê uma informação superficial. Já a Confederação Brasileira de Basquetebol (CBB), define para equipamento Tipo-1 e 2 (Móvel), e Tipo 6 e 7 (Fixas ao chão) que as as normas da FIBA sejam seguidas.

Ressalta-se, neste estudo, que equipamentos diversos possuem características e sistemas diferenciados e podem possuir massa de até $2600 \mathrm{kgf}$. Na década de 1980 e 1990, os aros eram fixados na placa de vidro por meio de quatro parafusos presos ao vidro e ao braço de sustentação da tabela. No entanto, qualquer abalo era suficiente para quebrar e estilhaçar a placa de vidro provocando acidentes. Atualmente, esta falha foi corrigida e o aro é fixado na estrutura metálica, não mais no vidro da tabela.

Estes equipamentos são construídos com estrutura metálica (Tipo 1 e 2 - equipamentos móveis) ou com pilar em concreto armado ou em aço (Tipo 6 e 7 - equipamentos fixos). Por ser um sistema individual e solto, as fixações do Tipo 1 e 2 devem ser ancoradas ao piso da quadra para que o conjunto não venha a tombar sobre o praticante, conforme apresentado adiante neste estudo. Já, as estruturas de concreto armado e aço, Tipo 6 e 7, devem ter suas tabelas ensaiadas para que não causem acidentes, conforme preconiza a norma europeia EN EP 1270:2006. 
Verificou-se, em pesquisa de campo efetuada, que o Tipo 6 é a estrutura mais encontrada em quadras esportivas. (com pilar de concreto armado)

\section{DEFINIÇÃO CONSTRUTIVA PARA CONFECÇÃO DE TRAVES PARA FUTSAL}

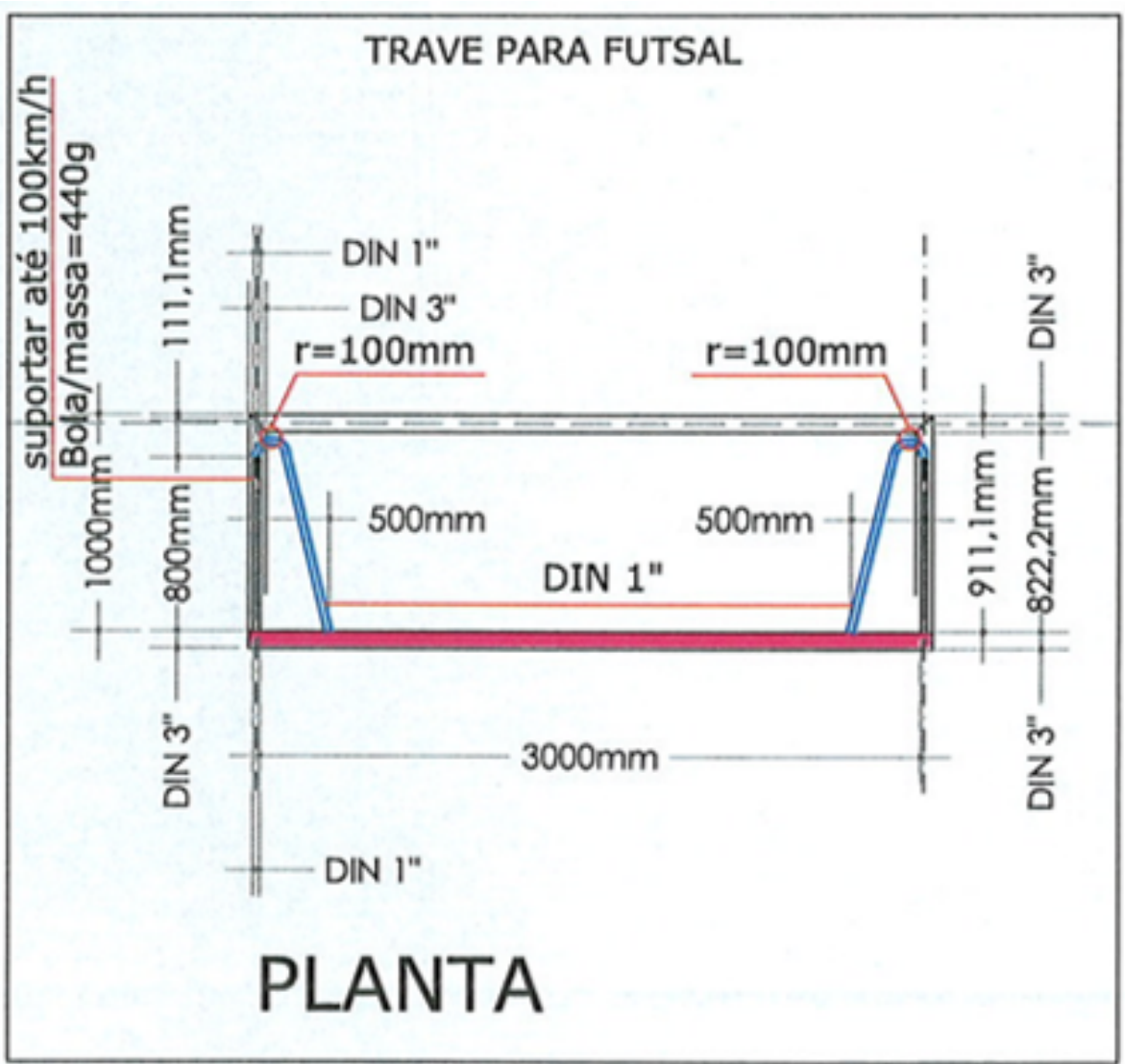

Figura 1 - Dimensões oficiais da trave e localização dos componentes - Planta. Fonte: Projeto do Autor 


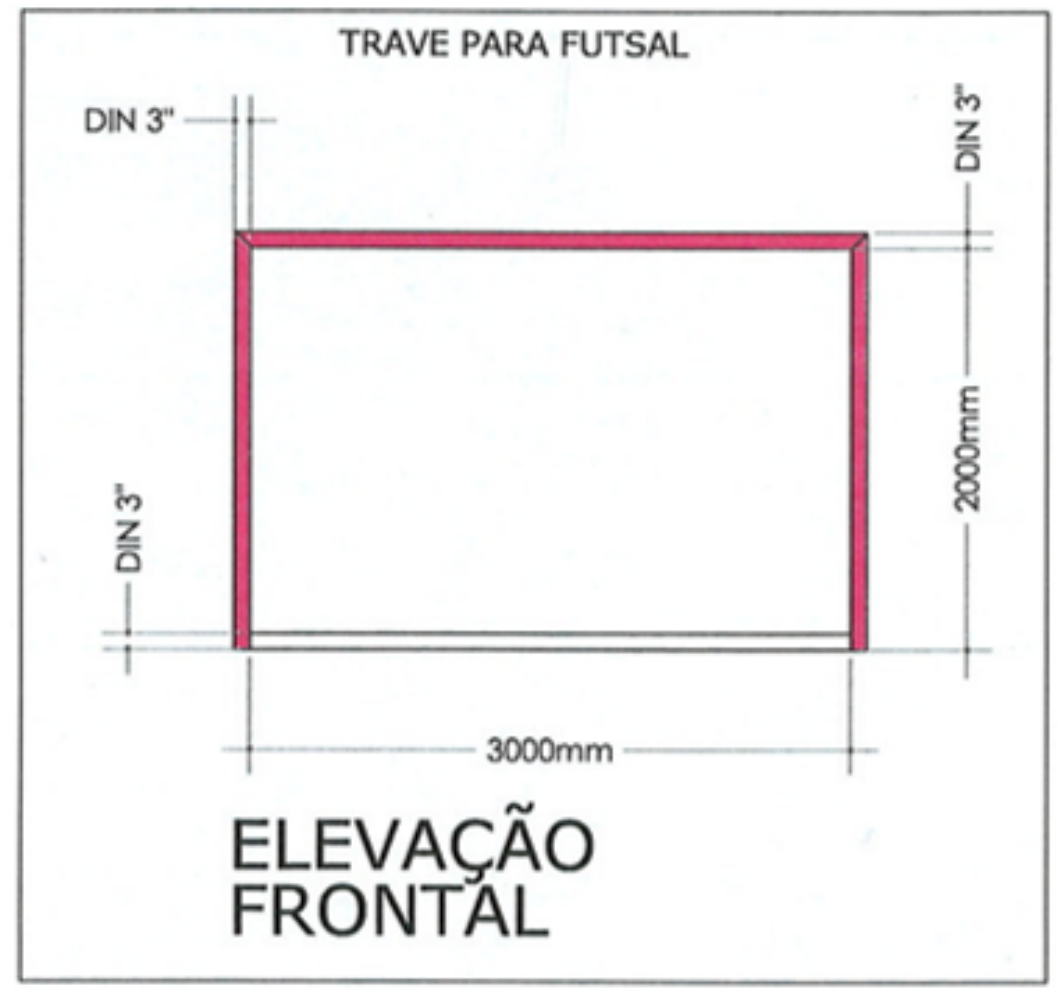

Figura 2 - Dimensões oficiais da trave e localização dos componentes - Elevação Frontal. Fonte: Projeto do Autor

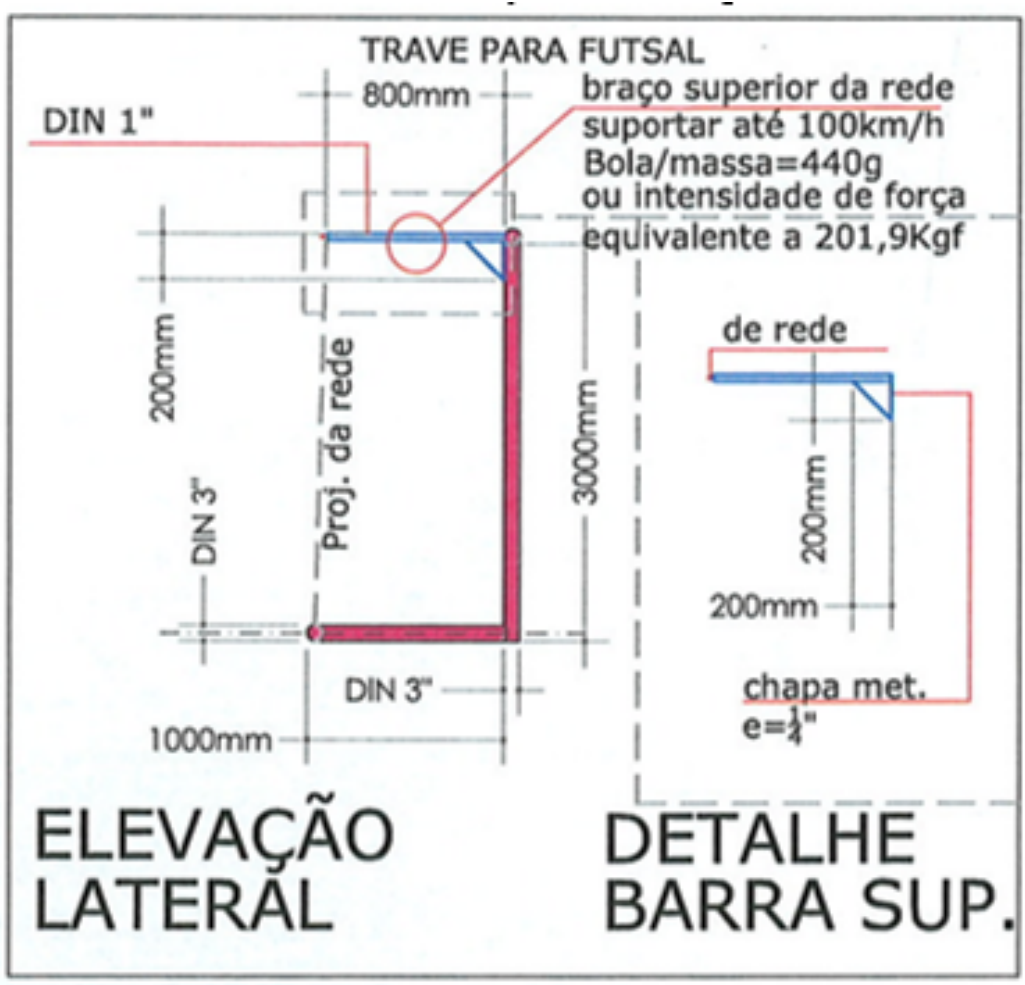

Figura 3 - Dimensões oficiais da trave e localização dos componentes - Elevação Lateral e detalhe. Fonte: Projeto do Autor 
5.1 Sistema proposto de fixação não permanente de traves

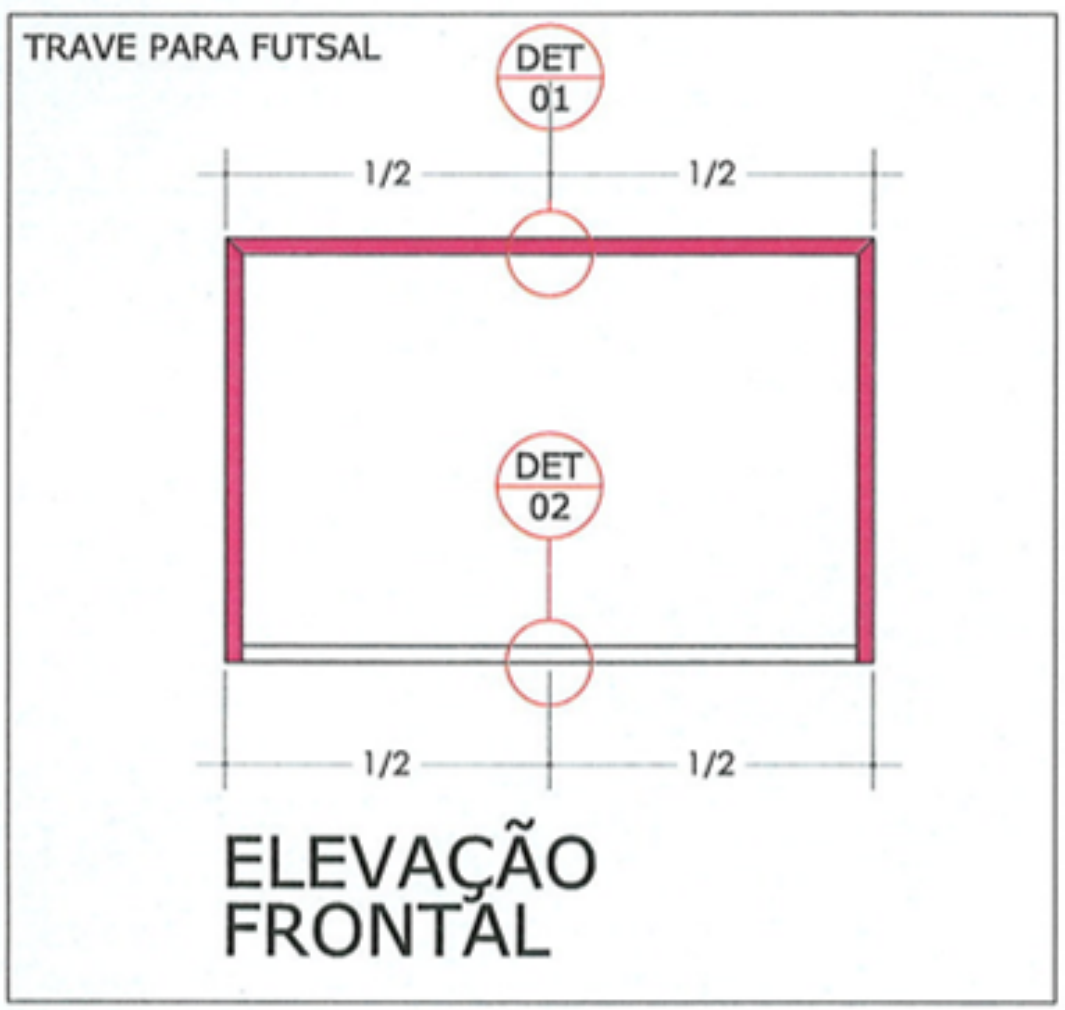

Figura 4 - Localização dos pontos de ancoragem na trave e no piso - Elevação Frontal. Fonte: Projeto do Autor

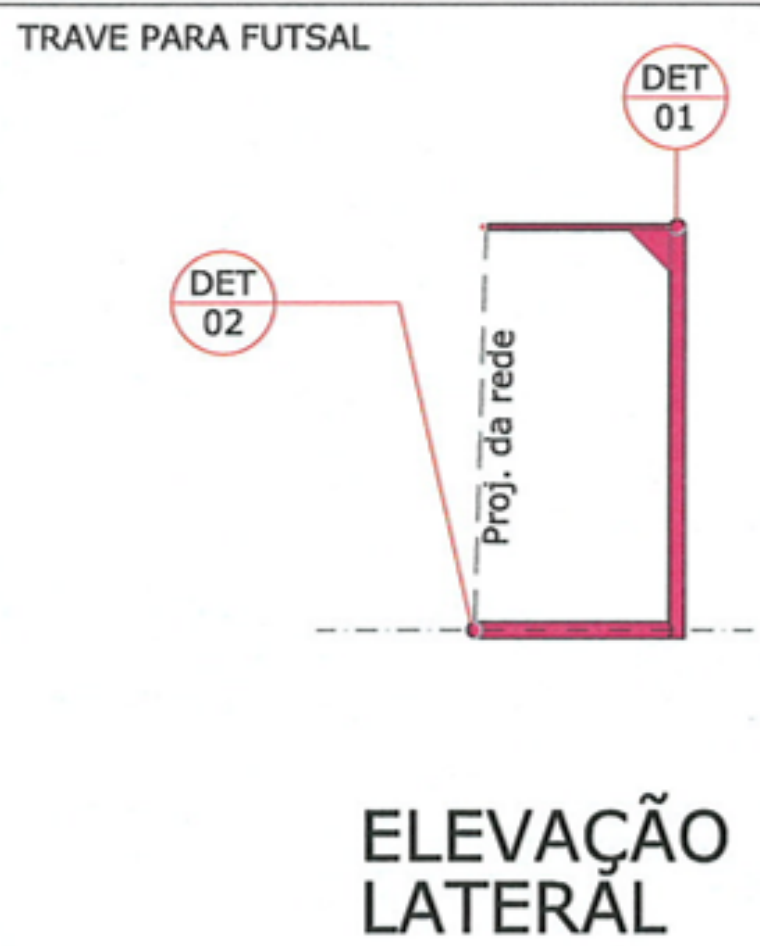

ancoragem no travessão e barra horizontal inferior. Fonte: Projeto do Autor 


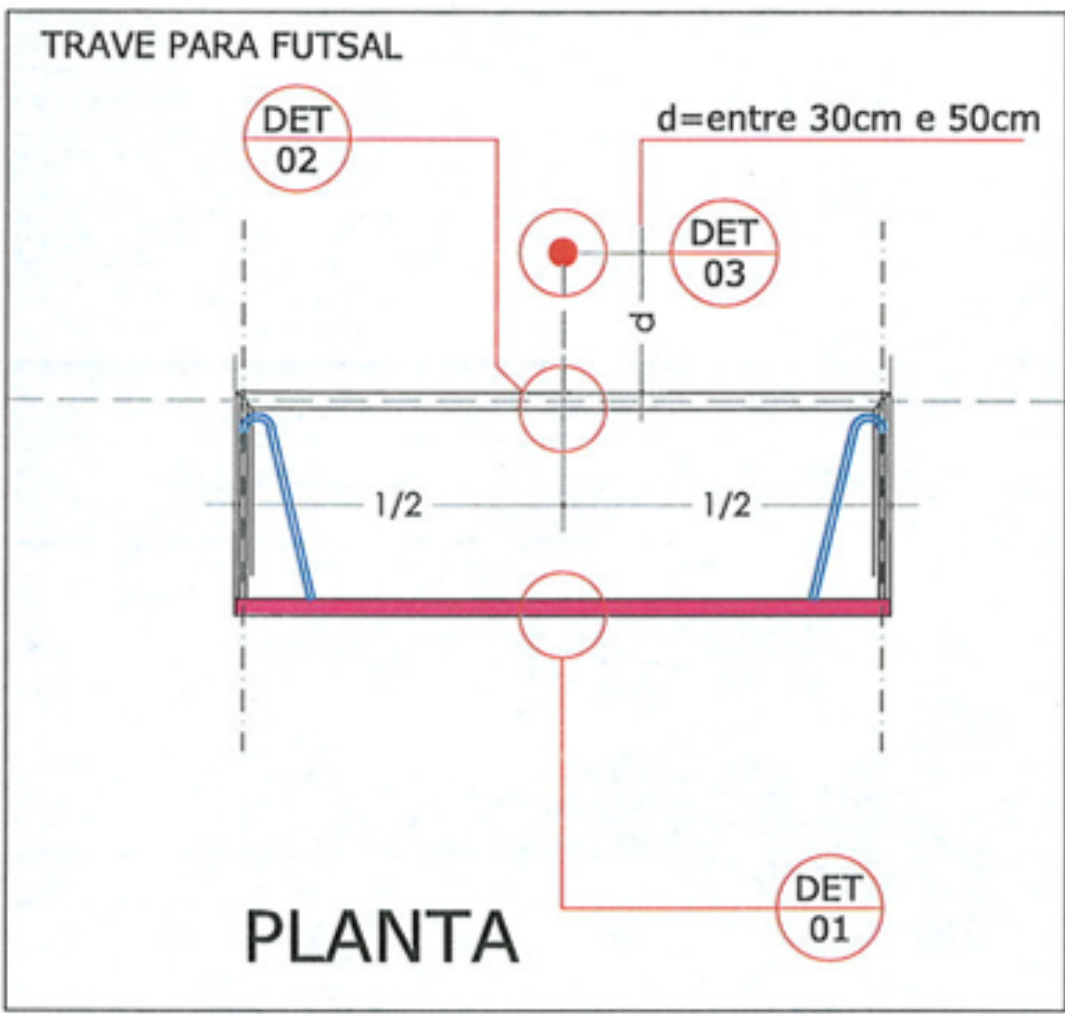

Figura 6 - Localização dos detalhes de ancoragem na trave, para fixação aérea ou no piso. Fonte: Projeto do Autor

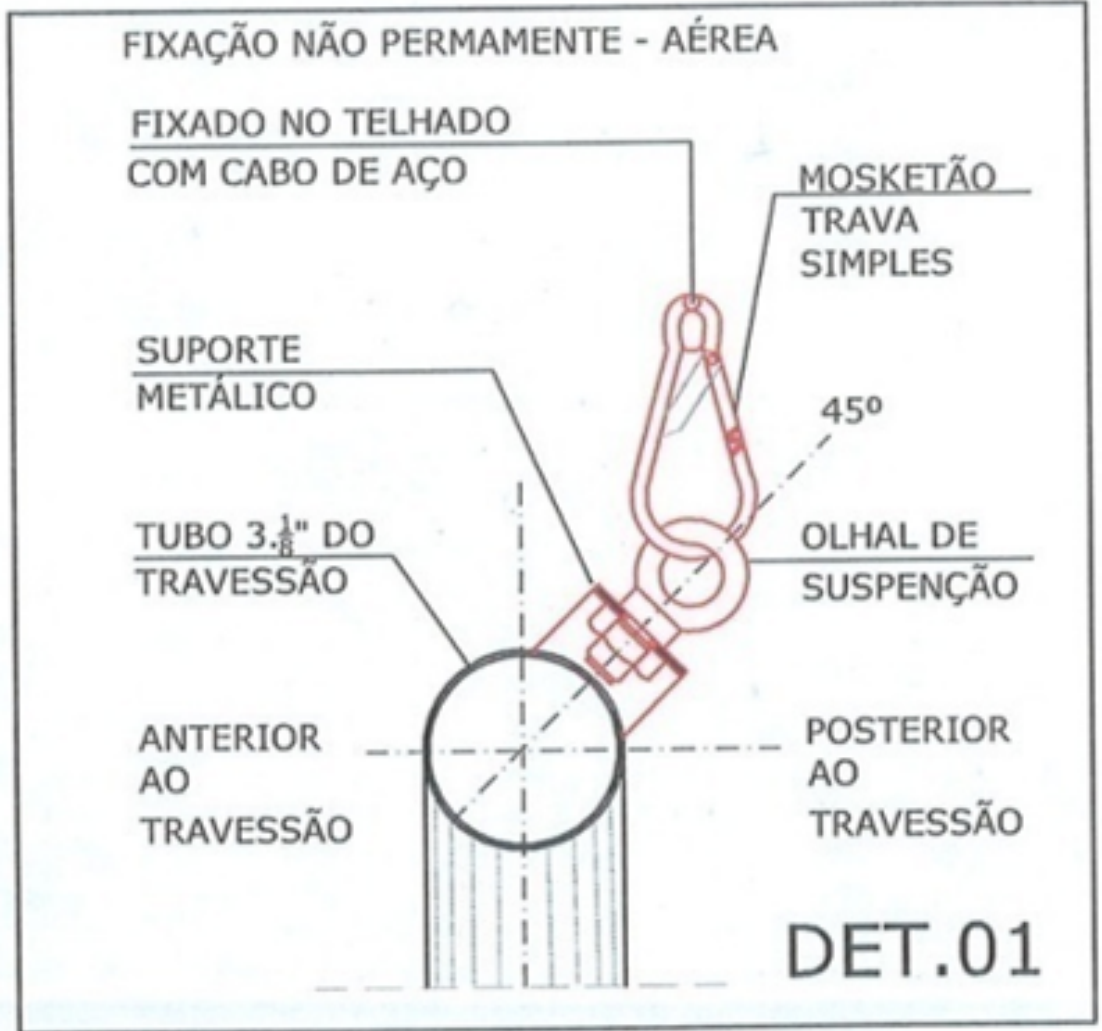

Figura 7 - Det. de fixação não permanente e aéreo, preso a estrutura da cobertura da quadra. Fonte: Projeto do Autor 


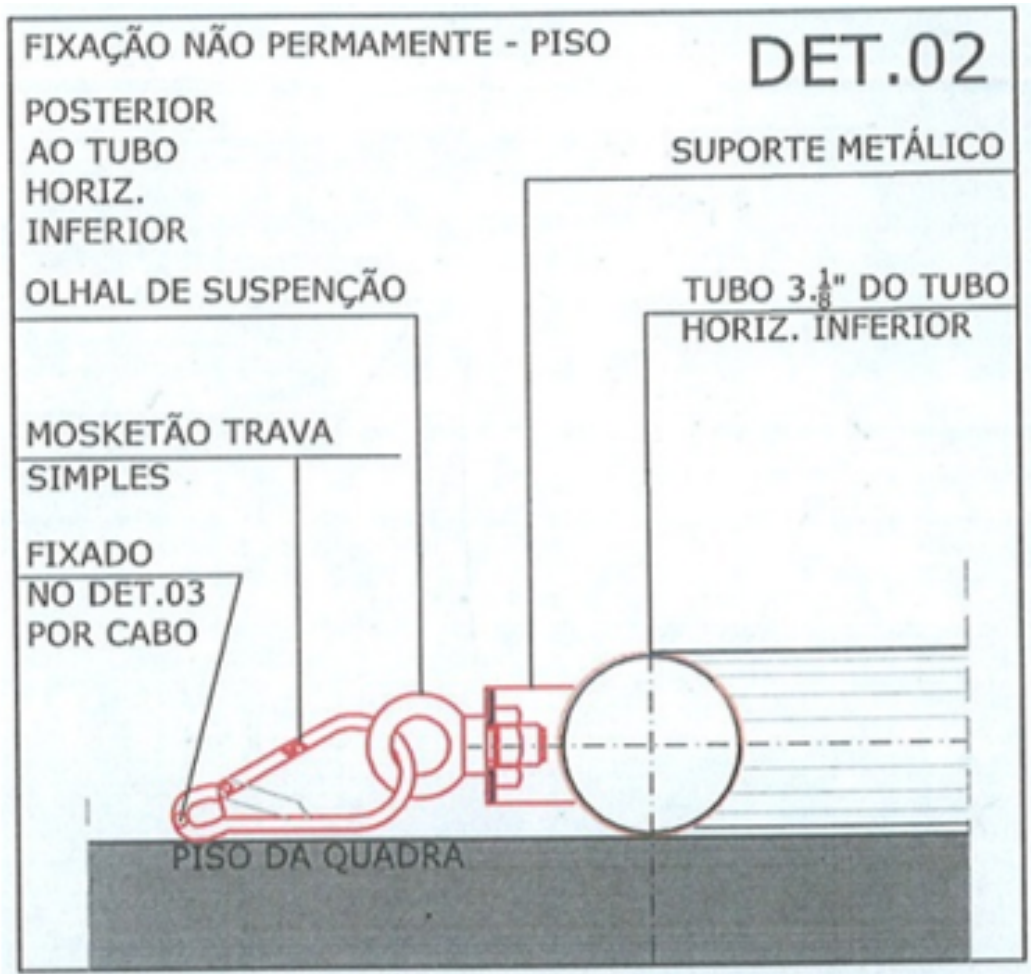

permanente no piso. Fonte: Projeto do Autor

Figura 8 - Detalhe de fixação não

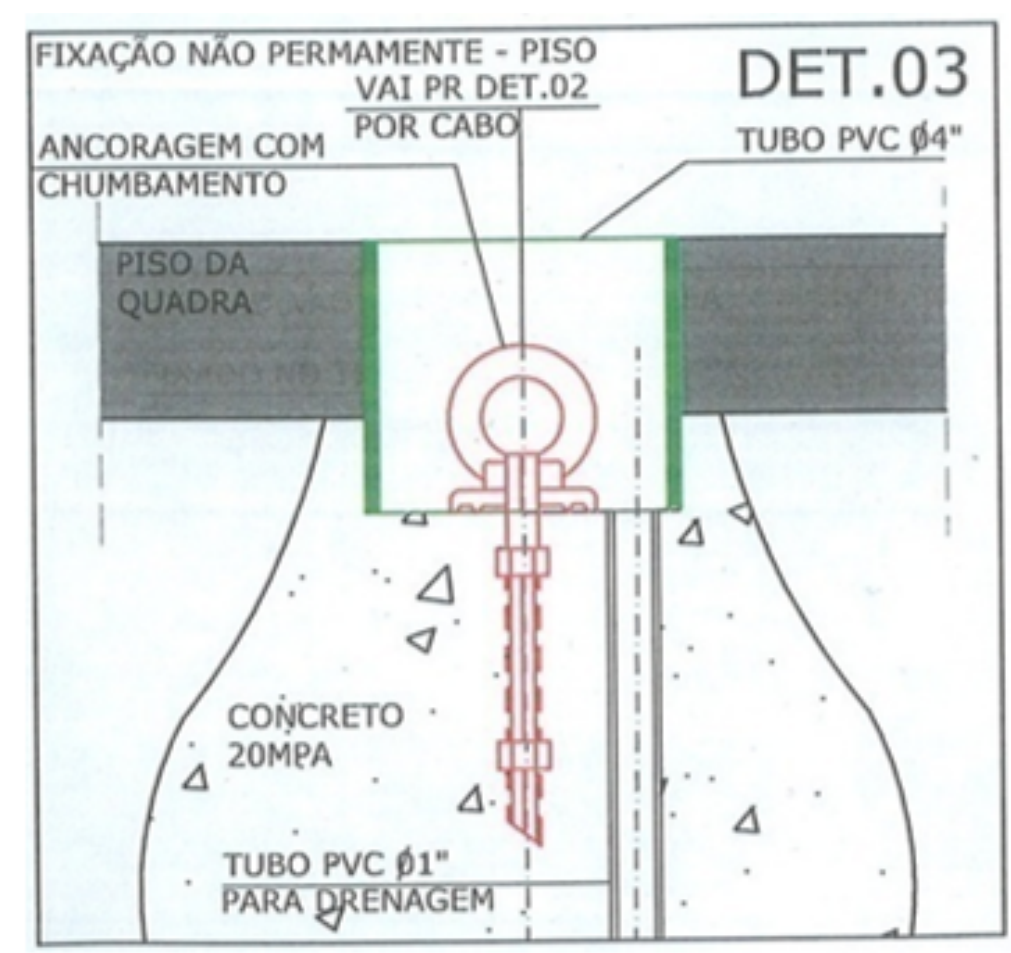

Figura 9 - Detalhe de fixação não permanente no piso, preso em gancho embutido no piso. Fonte: Projeto do Autor

De posse destas informações, o responsável pelo espaço esportivo deverá contratar os serviços de cálculo estrutural para execução da base de sustentação da trave, considerando-se um conjunto de trave com peso igual a $100 \mathrm{Kg}$ conforme projetado neste estudo, além de contemplar massa mínima de $120 \mathrm{Kg}$ para o 
indivíduo, que eventualmente possa atuar com força extra sobre o equipamento, de forma que a base venha a suportar os esforços de deslocamento total.

\subsection{Parâmetros que nortearam o detalhamento do sistema de fixação não permanente para traves de Futsal}

Tomou-se como base para o estudo, o impulso de uma criança de agarrar-se ao travessão da trave de futsal para se balançar.

As traves de quadras de futebol de salão, para as situações em que as mesmas não recebem fixação ao chão, (também erroneamente) podem provocar movimentações indevidas provocadas por inúmeras situações. Dentre as situações de perigo, coloca-se aqui a de uma criança, adolescente ou adulto que resolva utilizar a trave como barra de ginástica ou para aquecimento ou comemoração de um gol, e nela passe a fazer diversos movimentos que possam provocar oscilações na trave que a leve a cair sobre o corpo, atingindo cabeça, tronco ou abdome.

Para exemplificar a gravidade de tal circunstância, demonstra-se nos croquis abaixo, o cálculo da carga exercida pela queda da trave sobre o corpo de uma criança ao ser golpeada no momento do acidente. 

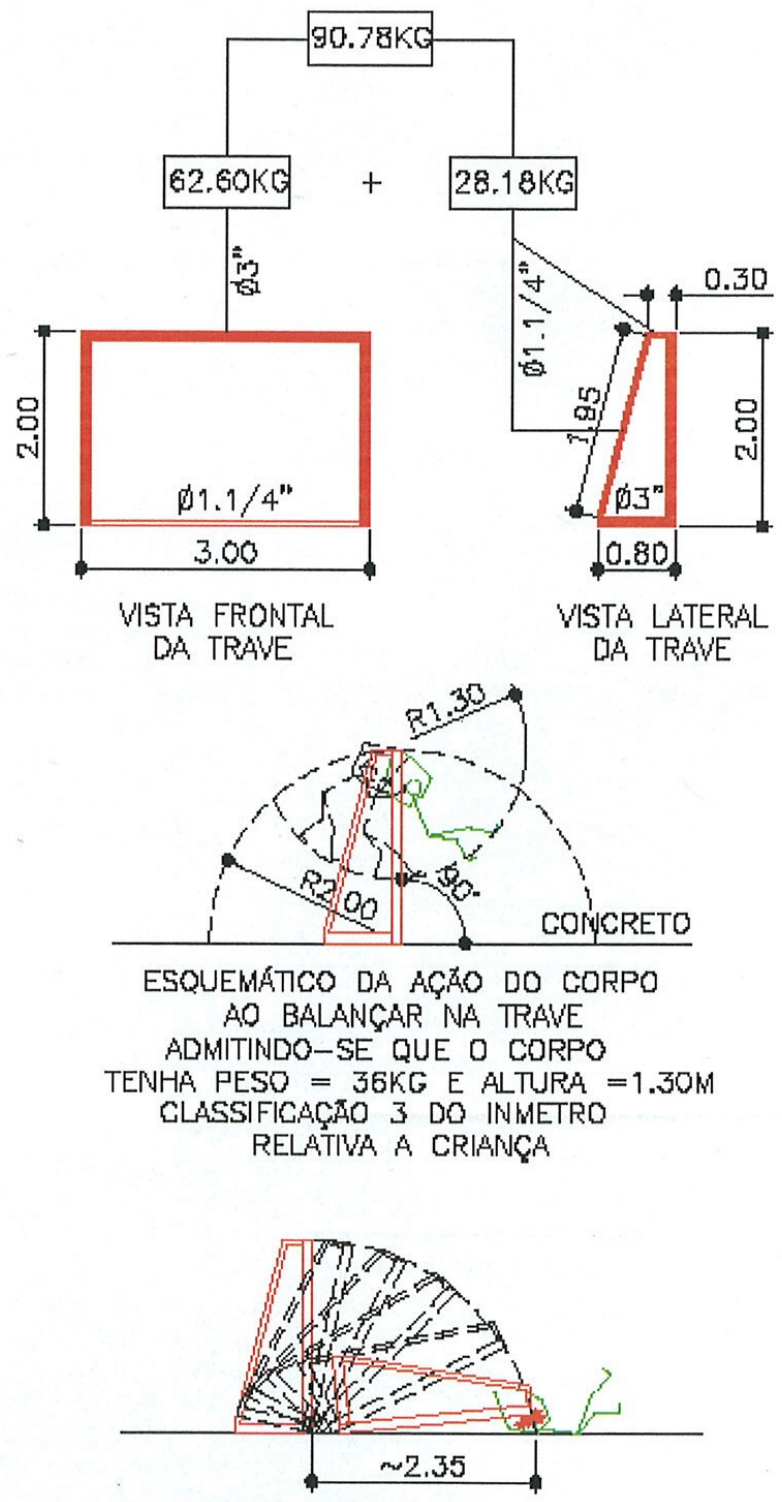

ESQUEMATICO DA ACAOO DA TRAVE

AO SER DESLOCADA DO PONTO DE REPOUSO

SENDO LANCADA EM QUEDA LIVRE

SOBRE O CORPO 
Figura 10 - Croqui Esquemático. Fonte: Desenho do Autor - Cálculo de Eng ${ }^{\circ}$ Alan Ferreirós

Croqui esquemático da criança ao se balançar na trave, utilizando dados padrão do INMETRO, admitindose que um corpo com peso de $36 \mathrm{Kg}$ e altura de $1,30 \mathrm{~m}$, classificação 3.

Esclarecendo que o "peso" comumente utilizado pela população se trata na verdade da massa de um corpo, assim sendo temos:

$\mathrm{P}=\mathrm{m} \cdot \mathrm{g}$, onde:

$\mathrm{P}=$ Força peso $(\mathrm{N})$

$\mathrm{m}=$ Quantidade de matéria (kgf)

$\mathrm{g}=$ Aceleração da gravidade $\left(\mathrm{m} / \mathrm{s}^{2}\right)$

Ou seja, força peso é igual à massa vezes a aceleração da gravidade (Segunda lei de Newton).

A aceleração da gravidade é constante e vale aproximadamente $9,81 \mathrm{~m} / \mathrm{s} 2$ na terra. (variável)

Logo, uma criança com "peso" de $36 \mathrm{~kg}$, significa na verdade que sua massa é de $36 \mathrm{kgf}$, segundo a fórmula acima, ela pesa:

$\mathrm{P}=\mathrm{m} \cdot \mathrm{g} ? \mathrm{P}=36 \times 9,81 ? \mathrm{P}=352,8 \mathrm{~N} ? \mathrm{M}=36 \mathrm{Kgf}$

O croqui acima apresenta as dimensões e especificação dos tubos de aço como representado, a trave é lançada para frente com o corpo da criança, havendo ainda um deslocamento da trave para frente, estimado em $35 \mathrm{~cm}$, no entanto, fato a complexidade do cálculo incluindo tal deslocamento, este não será considerado, porém o mesmo não é relevante para o valor final.

Os dados técnicos dos tubos atendem a NBR 5590/2012 - Tubos de aço-carbono com ou sem solda longitudinal, pretos ou galvanizados — Especificação. 


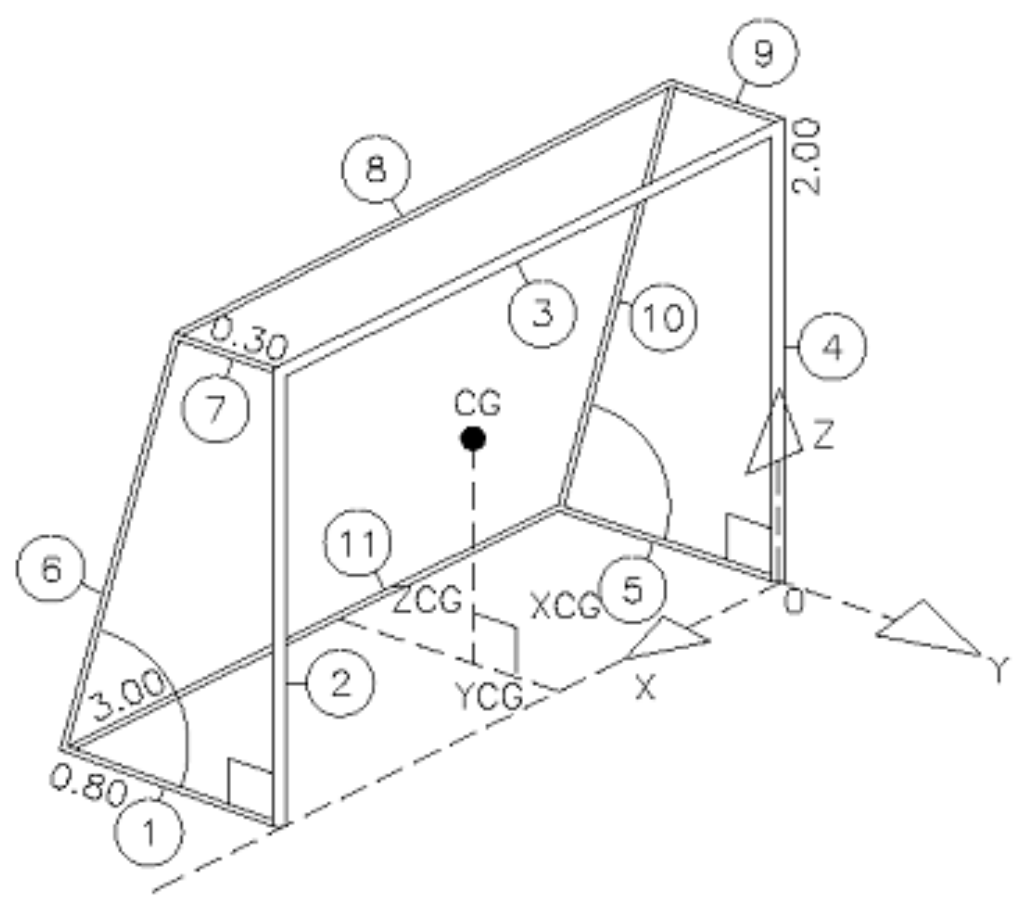

Figura 11 - Identificação das barras da trave para o cálculo abaixo. Fonte: Desenho do Autor - Cálculo de Eng ${ }^{\circ}$ Alan Ferreirós

\section{Barras 1, 2, 3, 4 e 5 [tipo 1]:}

Diâmetro:

$$
d_{1}=3^{\prime \prime}=0,0762 m
$$

Densidade linear:

$$
p_{1}=\frac{62,60}{0,8+2+3+2+0,8}=7,28 \mathrm{~kg} / \mathrm{m}
$$

\section{Barras 6, 7, 8, 9, 10 e 11 [tipo 2]:}

Diâmetro: 


$$
d_{2}=\frac{1,1^{\prime \prime}}{4}=0,007 \mathrm{~m}
$$

Densidade linear:

$$
\begin{gathered}
X_{c g}=\frac{3}{2}=1,5 \mathrm{~m} \\
Y_{c g}=\frac{2 \frac{0,8}{2}\left(0,8 \rho_{1}\right)+2 \frac{0,3}{2}\left(0,3 \rho_{2}\right)+0,3\left(3 \rho_{2}\right)+0,8\left(3 \rho_{2}\right)+2 \frac{2,06 \cos \beta}{2}\left(2,06 \rho_{2}\right)}{90,78}=0,17 \mathrm{~m} \\
Z_{c g}=\frac{2 \frac{2}{2}\left(2 \rho_{1}\right)+2 \frac{2}{2}\left(2,06 \rho_{2}\right)+2\left(3 \rho_{2}\right)+2\left(3 \rho_{1}\right)}{90,78}=1,10 \mathrm{~m}
\end{gathered}
$$

Centro de gravidade (CG):

$$
\begin{gathered}
X_{c g}=\frac{3}{2}=1,5 m \\
Y_{c g}=\frac{2 \frac{0,8}{2}\left(0,8 \rho_{1}\right)+2 \frac{0,3}{2}\left(0,3 \rho_{2}\right)+0,3\left(3 \rho_{2}\right)+0,8\left(3 \rho_{2}\right)+2 \frac{2,06 \cos \beta}{2}\left(2,06 \rho_{2}\right)}{90,78}=0,17 m \\
Z_{c g}=\frac{2 \frac{2}{2}\left(2 \rho_{1}\right)+2 \frac{2}{2}\left(2,06 \rho_{2}\right)+2\left(3 \rho_{2}\right)+2\left(3 \rho_{1}\right)}{90,78}=1,10 \mathrm{~m}
\end{gathered}
$$

Momento de inércia em relação à origem (0): 


$$
\mathrm{J}_{0}=\mathrm{J}_{1}+\mathrm{J}_{2}+\mathrm{J}_{3}+\mathrm{J}_{4}+\mathrm{J}_{5}+\mathrm{J}_{6}+\mathrm{J}_{7}+\mathrm{J}_{8}+\mathrm{J}_{9}+\mathrm{J}_{10}+\mathrm{J}_{11}
$$

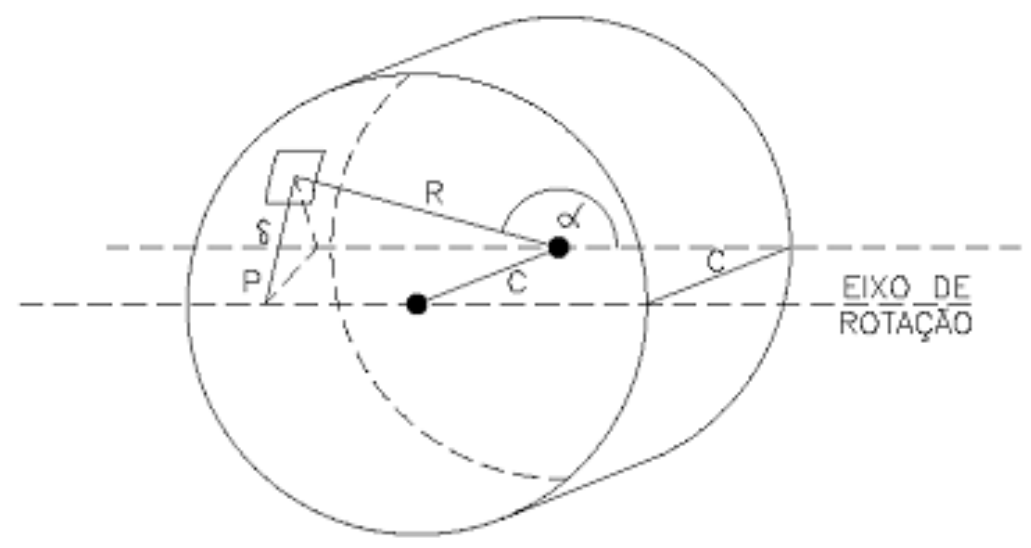

Figura 12 - Eixo de rotação do cilindro concentrado no piso-01. Fonte: Desenho do Autor - Cálculo de Eng ${ }^{\circ}$ Alan Ferreirós

Supondo que todas as barras sejam "cascas" cilíndricas, como peso concentrado na superfície, eixo perpendicular:

Onde:

$$
d m=\rho r d \alpha d c
$$

$\mathrm{dm}$ : elemento de massa

$\rho$ : densidade linear

r: raio

$\mathrm{d}(\alpha)$ : elemento de ângulo dc: elemento de comprimento

$$
M=2 \pi r \rho C
$$

Onde:

C: comprimento da barra

r: raio 


$$
\begin{gathered}
\delta^{2}=c^{2}+(r \operatorname{sen} \alpha)^{2} \\
\mathrm{~J}_{c_{1}}=\int_{0}^{M} \delta^{2} d m \\
\mathrm{~J}_{c_{1}}=\int_{0}^{C} \int_{0}^{2 \pi}\left(c^{2}+r^{2} \operatorname{sen}^{2} \alpha\right) r \rho d \alpha d c \\
\mathrm{~J}_{c_{1}}=\int_{0}^{C} 2 \pi c^{2} r \rho d c=2 \pi r \rho \frac{1}{3} C^{3}=2 \pi r \rho C \frac{1}{3} C^{2}=\frac{1}{3} M C^{2}
\end{gathered}
$$

Em relação ao centro de gravidade:

$$
\frac{2}{3} M\left(\frac{C}{2}\right)^{2}=\frac{1}{6} M C^{2}
$$

\section{Eixo paralelo}

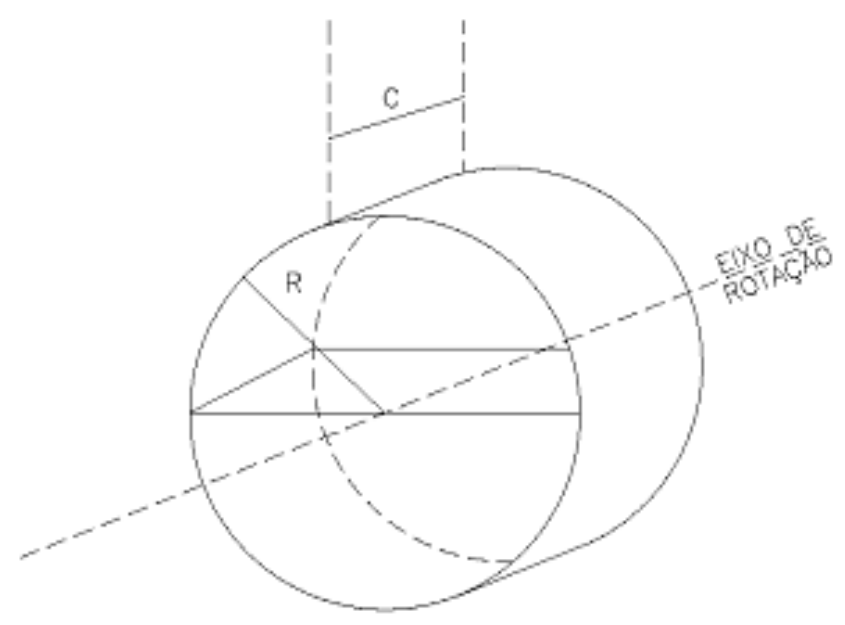

Figura 13 - Eixo de rotação do cilindro concentrado no piso-02. Fonte: Desenho do Autor - Cálculo de Eng ${ }^{\circ}$ Alan Ferreirós 


$$
\mathrm{J} C_{2}=\int_{0}^{M} r^{2} d m=\int_{0}^{C} \int_{0}^{22}\left(r^{2}\right) r \rho d \alpha d c=\int_{0}^{C} r^{3} \rho 2 \pi d c=2 \pi r^{3} C=2 \pi r C r^{2}=M r^{2}
$$

Momento de inércia de cada barra em relação ao eixo $\mathrm{X}$

$$
\begin{gathered}
\mathrm{J}_{1}=\mathrm{J}_{5}=\frac{1}{3}\left(0,8 \rho_{1}\right) * 0,8^{2} \cong 1,24 \mathrm{kgm}^{2} \\
\mathrm{~J}_{2}=\mathrm{J}_{4}=\frac{1}{3}\left(2 \rho_{1}\right) * 2^{2} \cong 1,94 \mathrm{kgm}^{2} \\
\mathrm{~J}_{3}=\left(3 * \rho_{1}\right)(\underbrace{\left.\frac{d_{1}}{2}\right)^{2}+\left(3 \rho_{1}\right) * 2^{2} \cong 87,39 \mathrm{kgm}^{2}}
\end{gathered}
$$

Teorema dos eixos paralelos

$$
\begin{gathered}
\mathrm{J}_{8}=\left(3 \rho_{1}\right)\left(\frac{d_{2}}{2}\right)^{2}+\left(3 \rho_{1}\right) *\left({\sqrt{2^{2}+0,3^{2}}}^{2} \cong 32,88 \mathrm{kgm}^{2}\right. \\
\mathrm{J}_{11}=\left(3 \rho_{1}\right) *\left(\frac{d_{2}}{2}\right)^{2}+\left(3 \rho_{21}\right) * 0,8^{2} \cong 5,15 \mathrm{kgm}^{2} \\
\mathrm{~J}_{6}=\mathrm{J}_{10}=\frac{1}{6}\left(2,06 \rho_{2}\right) * 2,06^{2}+\left(2,06 * \rho_{2}\right) *\left({\left.\sqrt{1^{2}+\left(\frac{0,3}{2}\right)^{2}}\right)^{2} \cong 9,77 \mathrm{kgm}^{2}}_{\mathrm{J}_{7}=\mathrm{J}_{9}=} \frac{1}{6}\left(0,3 \rho_{2}\right) * 0,3^{2}+\left(0,3 \rho^{2}\right) *\left(\sqrt{2^{2}+\left(\frac{0,5}{2}\right)^{2}}\right)^{2} \cong 3,25 \mathrm{kgm}^{2}\right.
\end{gathered}
$$

Portanto, o momento de inércia total é: 


$$
\mathrm{J}=\sum_{i=1}^{11} \mathrm{~J}_{i} \cong 157,82 \mathrm{kgm}^{2}
$$

\section{Modelo do movimento}

Por simplificação, considerou-se que o único movimento será a rotação em torno do eixo e que a estrutura estará submetida apenas ao peso após o instante $\mathrm{t}_{1}$ :

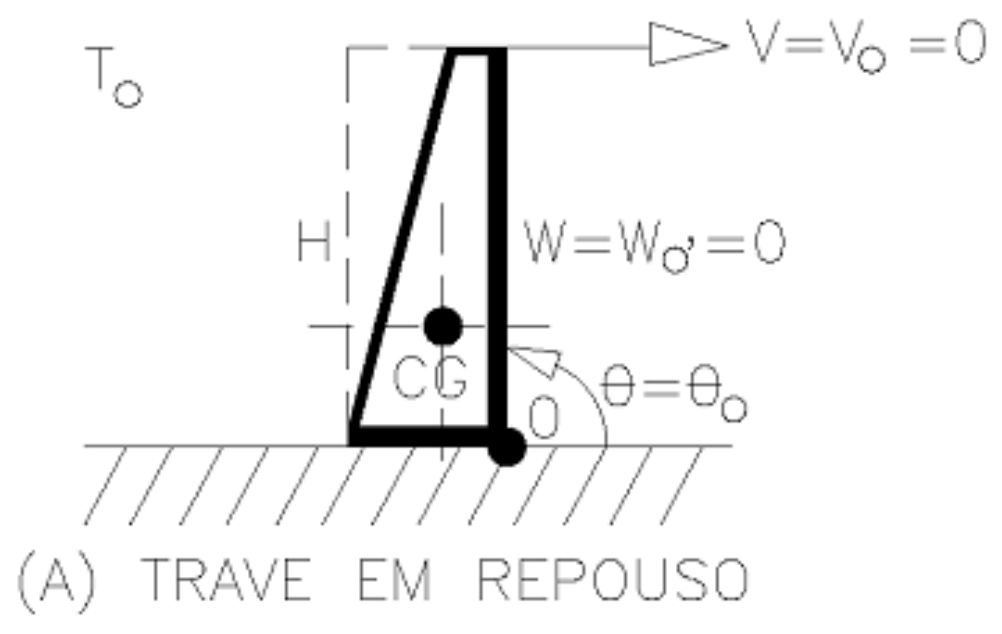

Fonte: Desenho do Autor - Cálculo de Engo Alan Ferreirós

Figura 14 - Trave em repouso. 


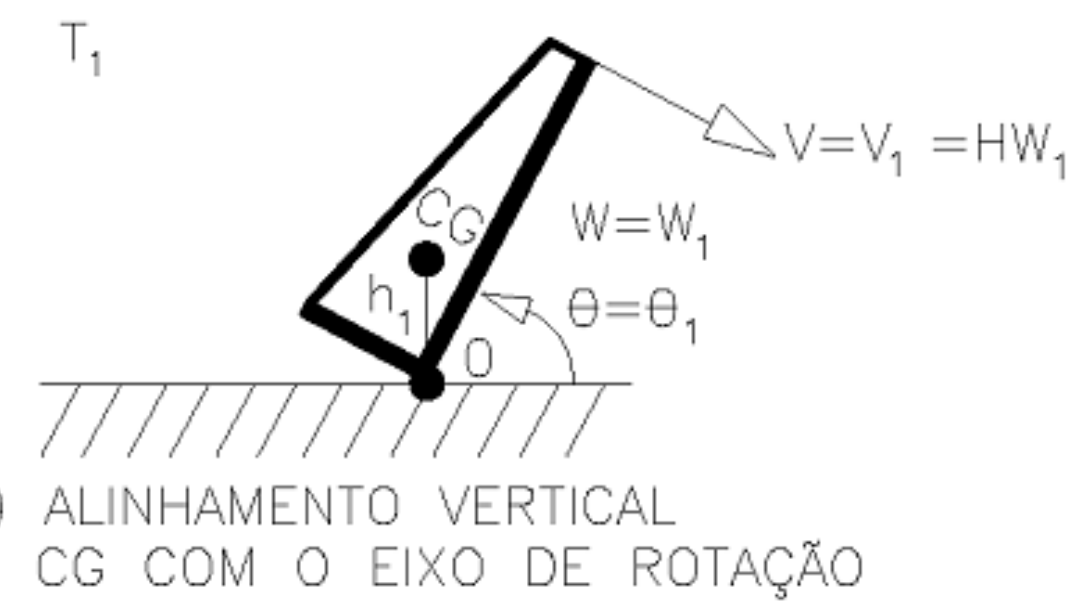

Figura 15 - Alinhamento vertical do CG com o eixo de rotação. Fonte: Desenho do Autor - Cálculo de Eng ${ }^{\circ}$ Alan Ferreirós
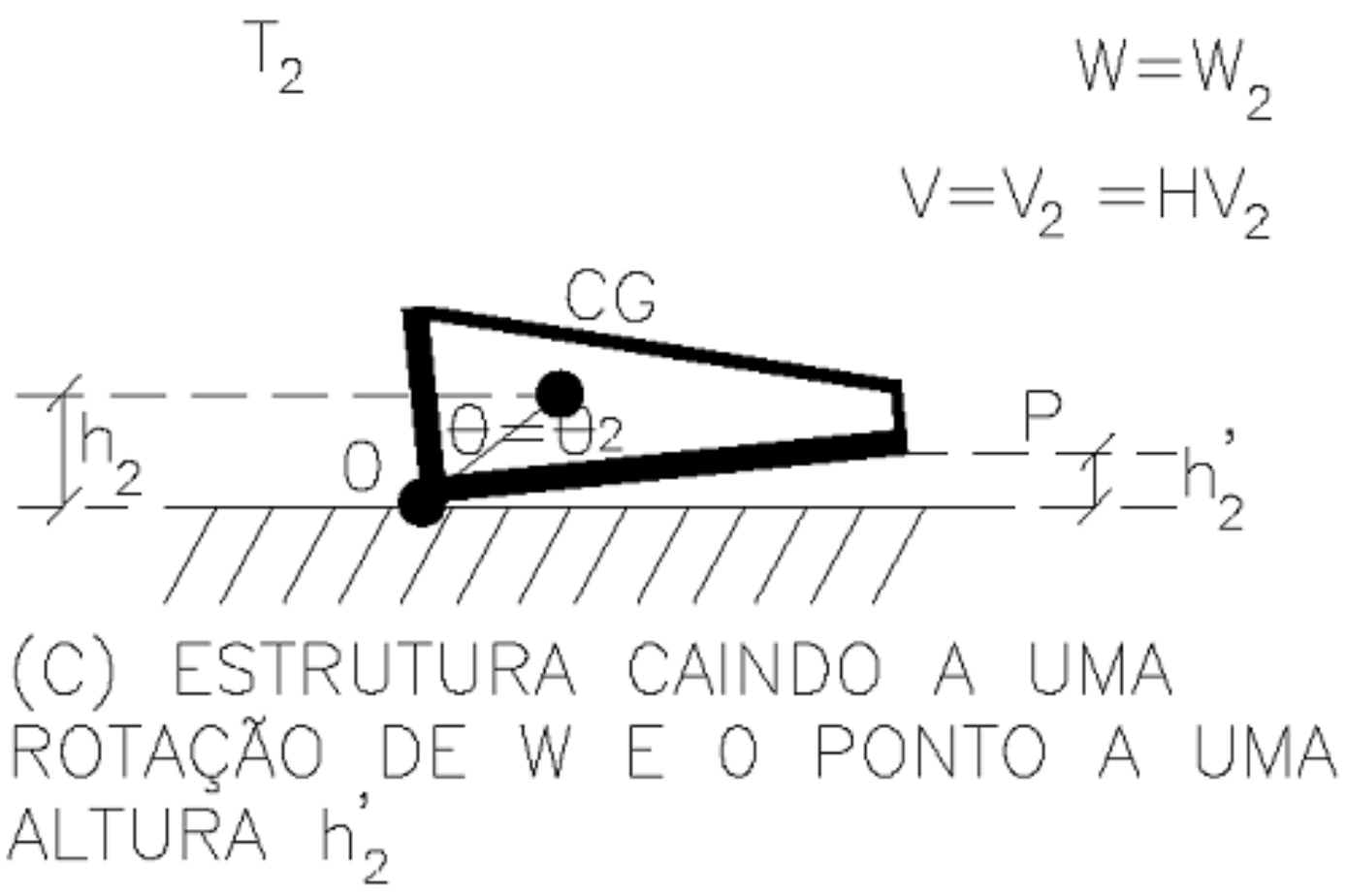

Figura 16 -

Estrutura caindo a uma rotação de "w" e "0" ponto a uma altura h2. Fonte: Desenho do Autor - Cálculo de Eng ${ }^{\circ}$ Alan Ferreirós

Nestas condições, podemos aplicar o princípio da conservação da energia para saber quanta energia deverá ser dissipada em $\mathrm{t}_{2}$ para parar completamente o movimento da estrutura. 


$$
\begin{gathered}
E_{1}=M g h_{1}+\frac{J \varpi_{1}^{2}}{2} \\
E_{2}=M g h_{2}+E_{D}
\end{gathered}
$$

Onde, $\mathrm{M}$ é a massa total, $\mathrm{g}$ é a aceleração da gravidade, $\mathrm{h}_{1}$ é a altura do centro de massa em $\mathrm{t}_{1}$, ? é o momento de inércia e $?_{1}$ é a velocidade angular em $\mathrm{t}_{1}$ : Ed é a energia a ser dissipada em $\mathrm{t}_{2}$.

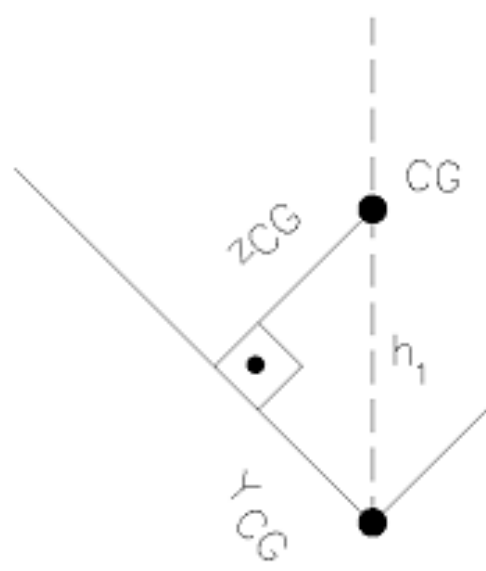

Figura 17 - Gráfico do princípio da conservação de energia para obter energia a ser dissipada. Fonte: Desenho do Autor - Cálculo de Eng ${ }^{\circ}$ Alan Ferreirós 
Portanto,

$$
h_{1}=\sqrt{Y_{c G}{ }^{2}+Z_{c G}{ }^{2}}
$$

$$
E=M g \sqrt{Y_{c G}{ }^{2}+Z_{c G}{ }^{2}+\frac{U \varpi_{1}^{2}}{2}}
$$

Se $\varpi_{1}=0 \mathrm{rad} / \mathrm{s}:$

$$
\begin{gathered}
E_{1}=90,78 * 10 * \sqrt{0,17^{2}+1,10^{2}} \cong 1010 \mathrm{~J} \\
E_{D}=E_{1}-M g h_{2}
\end{gathered}
$$

Para $h_{2}^{1}=0,25 m(25 \mathrm{~cm})$ :

$$
\begin{gathered}
E_{D}=1010-90,78 * 10 * h_{2} \\
h_{2}=0,31 m
\end{gathered}
$$

\section{Portanto:}

$$
E_{D}=729 \mathrm{~J}
$$

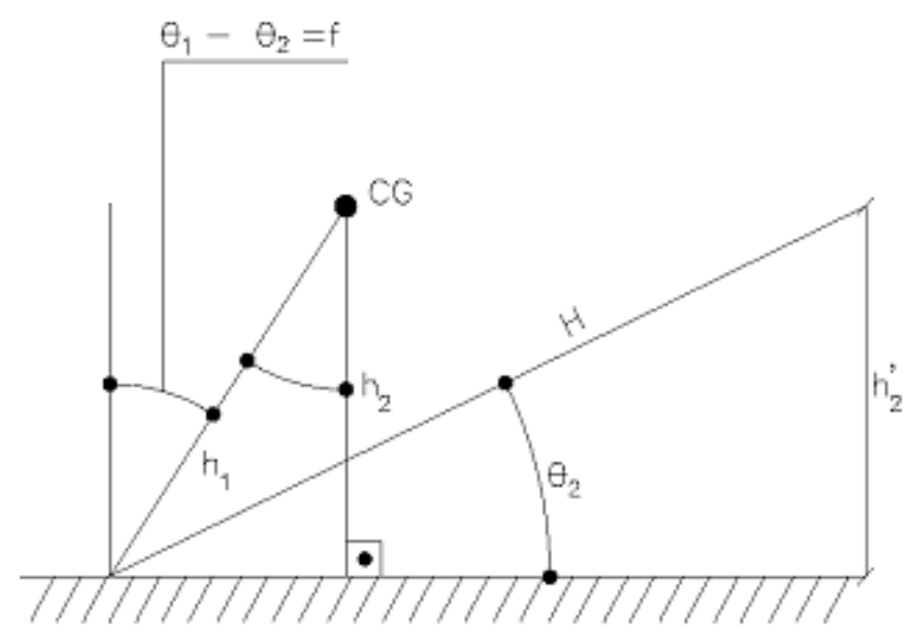

Figura 18 - Gráfico para obter a energia cinética através da velocidade angular. Fonte: Desenho do Autor - Cálculo de Eng ${ }^{\circ}$ Alan Ferreirós 


$$
\begin{gathered}
h_{2}=H \operatorname{sen} \theta_{2} \rightarrow \theta_{2}=\operatorname{arcsen}\left(\frac{h_{2}}{H}\right) \\
\theta_{1}=\operatorname{arctg}\left(\frac{Z_{c G}}{Y_{c G}}\right) \\
\gamma=\theta_{1}-\theta_{2} \\
h_{2}=h_{1} \cos \gamma
\end{gathered}
$$

Logo,

$$
h_{2}=\sqrt{Y c G^{2}+Z c G^{2} * \cos \left(\operatorname{arctg}\left(\frac{Z c G}{Y c G}\right) * \operatorname{arcsen}\left(\frac{h_{2}^{\prime}}{H}\right)\right.}
$$

Nestas condições, a velocidade angular pode ser obtida pela energia cinética:

$$
E_{D}=\frac{J \varpi_{2}^{2}}{2} \rightarrow \varpi_{2}=\sqrt{2 \frac{E_{D}}{J}}=\sqrt{2 \frac{729}{157,81}} \cong 3,0 \mathrm{rad} / \mathrm{s}
$$

E a velocidade na extremidade $(\mathrm{P})$ será: 


$$
v_{2}=H * \varpi_{2}=2 * 3,0=6 \frac{\mathrm{m}}{\mathrm{s}} \rightarrow 6 * 3,6=\mathbf{2 1}, \mathbf{6} \mathbf{k m} / \mathbf{h}
$$

A energia dissipada é a mesma energia de uma bola de boliche $(5 \mathrm{~kg})$ lançada a uma velocidade de $\sqrt{2 \frac{E_{D}}{5}} \cong 17 \frac{\mathrm{m}}{\mathrm{s}} \rightarrow 17 * 3,6 * \mathbf{6 1}, \mathbf{2} \mathbf{k m} / \mathbf{h}$ $0,5 \mathrm{rad} / \mathrm{s}:$

Cabe lembrar que esta energia foi calculada para: $\varpi_{1}=0 \mathrm{rad} / \mathrm{s}$ e posteriormente $\varpi_{1}=$

$$
\begin{gathered}
E_{1}=90,78 * 10 * \sqrt{0,17^{2}+1,10^{2}}+\frac{157,82 * 0,5^{2}}{2} \cong 1030 \mathrm{~J} \\
E_{D}=1030-90,78 * 10 * 0,31 \cong 748 \mathrm{~J} \\
\varpi_{2}=\sqrt{2 \frac{748}{157,82} \cong 3,1 \mathrm{rad} / \mathrm{s}} \\
v_{2}=H * \varpi_{1}=2 * 3,1=6,2 \mathrm{~m} / \mathrm{s}
\end{gathered}
$$

Cálculos: Eng ${ }^{\circ}$ Alan Ferreirós

Os ferimentos com a configuração demonstrada no croqui são graves e a morte é o resultado de trauma contundente na cabeça, pescoço ou tórax.

Na maioria dos casos pesquisados, isso ocorreu quando a trave cai acidentalmente sobre a vítima, quando a criança ou adolescente usa a trave para se balançar ou quando da sua remoção de lugar, no entanto isto ocorre também com jovens e adultos ao usarem a trave para aquecimento, usando a trave para fazer os exercícios, o acidente acontece da mesma forma.

Ventos fortes também podem causar este tipo de acidente ou transporte da trave para outro local.

Com a queda da trave, os ferimentos são graves, podendo levar à morte por causa do trauma contundente na cabeça, pescoço ou tórax.

Para uma criança de $1,36 \mathrm{~m}$ de altura e massa corporal de $36 \mathrm{Kg}$, a velocidade da queda do travessão é equivalente a $21,6 \mathrm{Km} / \mathrm{h}$ e a energia dissipada é a mesma de uma bola de boliche $(5 \mathrm{~kg})$ lançada a uma velocidade de $61,2 \mathrm{Km} / \mathrm{h}$. Assim, ao cair a criança tende a ficar com o membro superior sob o travessão, o que resulta em trauma contundente na cabeça, pescoço ou tórax. 


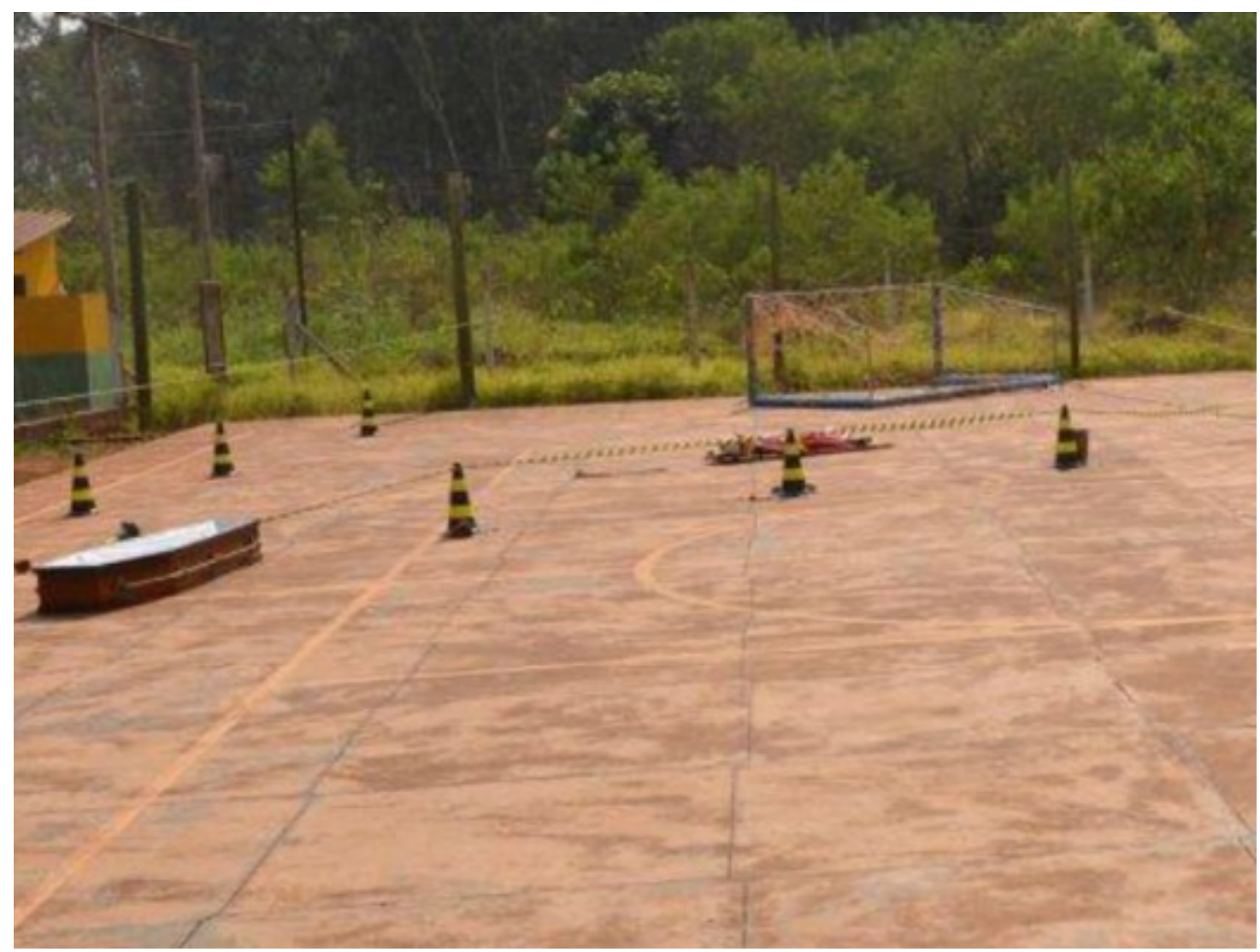

Imagem $01 \quad-$

Acidente com trave sobre menina, vindo à óbito. Fonte: http://g1.globo.com/mato-grosso-dosul/noticia/2012/09/menina-de-5-anos-morre-atingida-por-trave-de-quadra-esportiva-em-ms.html

"Uma menina de 5 anos morreu ao ser atingida pela trave de uma quadra de esportes quando brincava no local quando a estrutura tombou e caiu em cima dela."

\subsection{Parâmetros que nortearam o detalhamento do esquema para traves de Futsal}

Premissas para o cálculo de uma bola de Futsal ao se chocar com a barra superior de sustentação da rede: (Para definição segura da barra superior lateral ao conjunto da trave)

Massa da bola $=440 \mathrm{~g}$

Velocidade adotada para a bola: $100 \mathrm{Km} / \mathrm{h}$ (O recorde estabelecido pelo Guinness World Records é de $129 \mathrm{~km} / \mathrm{h}$, neste estudo adotou-se $108 \mathrm{~K} / \mathrm{h}$ ou $30 \mathrm{~m} / \mathrm{s}$ )

Segundo C.E. Aguiar; G. Rubini (2004) Físicos do Instituto de Física da Universidade Federal do Rio de Janeiro, a velocidade máxima que jogadores profissionais conseguem dar à bola de futebol é da ordem de $30 \mathrm{~m} / \mathrm{s}$.

\subsubsection{Energia cinética}

\section{Análise A:}


Quando um corpo de massa "m" está se movendo a uma velocidade "v", ele possui energia cinética $\mathrm{E}_{\mathrm{c}}$ que é dada pela seguinte equação:

$\mathrm{E}_{\mathrm{c}}=\mathrm{m} * \mathrm{v}^{2} / 2$

Logo:

$1 \mathrm{~km} / \mathrm{h}=1000 \mathrm{~m} / 3600 \mathrm{~s}$

$1 \mathrm{~km} / \mathrm{h}=(1 / 3,6) \mathrm{m} / \mathrm{s}$ ou

$1 \mathrm{~m} / \mathrm{s}=3,6 \mathrm{~km} / \mathrm{h}$

$108 \mathrm{~km} / \mathrm{h} / 3,6 \mathrm{~m} / \mathrm{s}=30 \mathrm{~m} / \mathrm{s}$

$\mathrm{v}=30 \mathrm{~m} / \mathrm{s}$

$\mathrm{m}=0,44 \mathrm{Kg}$

Desta forma tem-se:

$\mathrm{E}_{\mathrm{c}}=\mathrm{m} * \mathrm{v}^{2} / 2$

$\mathrm{E}_{\mathrm{c}}=0,440 * 30^{2} / 2$

$\mathrm{E}_{\mathrm{c}}=0,440 * 900 / 2$

$\mathrm{E}_{\mathrm{c}}=396 / 2$

$\mathrm{E}_{\mathrm{c}}=198$ Joules $/(1 \mathrm{~N}=9.80665 \mathrm{kgf})=20,19 \mathrm{Kgf} . \mathrm{m}$

$\mathrm{E}_{\mathrm{c}}=198$ Joules ou 20,19 Kgf.m

Esta energia cinética deverá ser anulada se a barra superior de sustentação da rede não perfurar a bola, (Razão pela qual a mesma foi projetada sem ponta aguda) sendo que no processo de interação da bola com esta barra, caso esta energia não for anulada, o centro de massa da bola se deslocará por uma distância "D". Esta distância "D" será a soma do recuo da barra com a deformação sofrida pela bola. (Ver foto abaixo) Esta deformação definirá o valor da força média que a bola causará na barra (ou o valor da força média que a barra fará na bola), para tal, esta estimativa de cálculo irá prever $15 \mathrm{~cm}$, (visto que o conjunto da trave com massa total de $66,2 \mathrm{Kg}$ encontra-se solto no piso) para este descolamento "D", ou seja, dividir-se á, a energia cinética de 198 Joules por "D" (15) cm. 


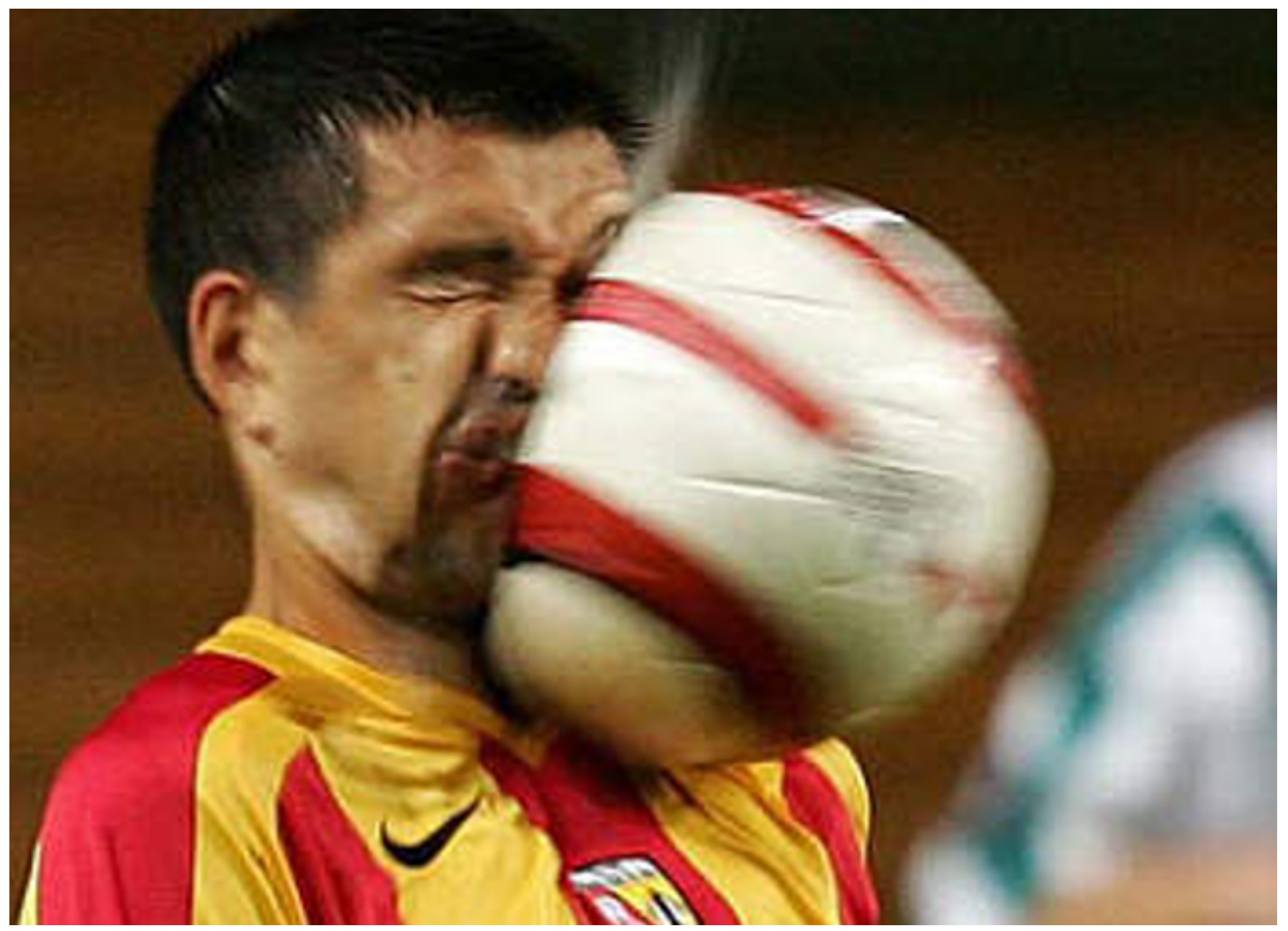

Imagem 02 - Deformação dos corpos. Fonte: Reuters: Eric Carriere, jogador do Lens, recebe uma espetacular bolada na cara

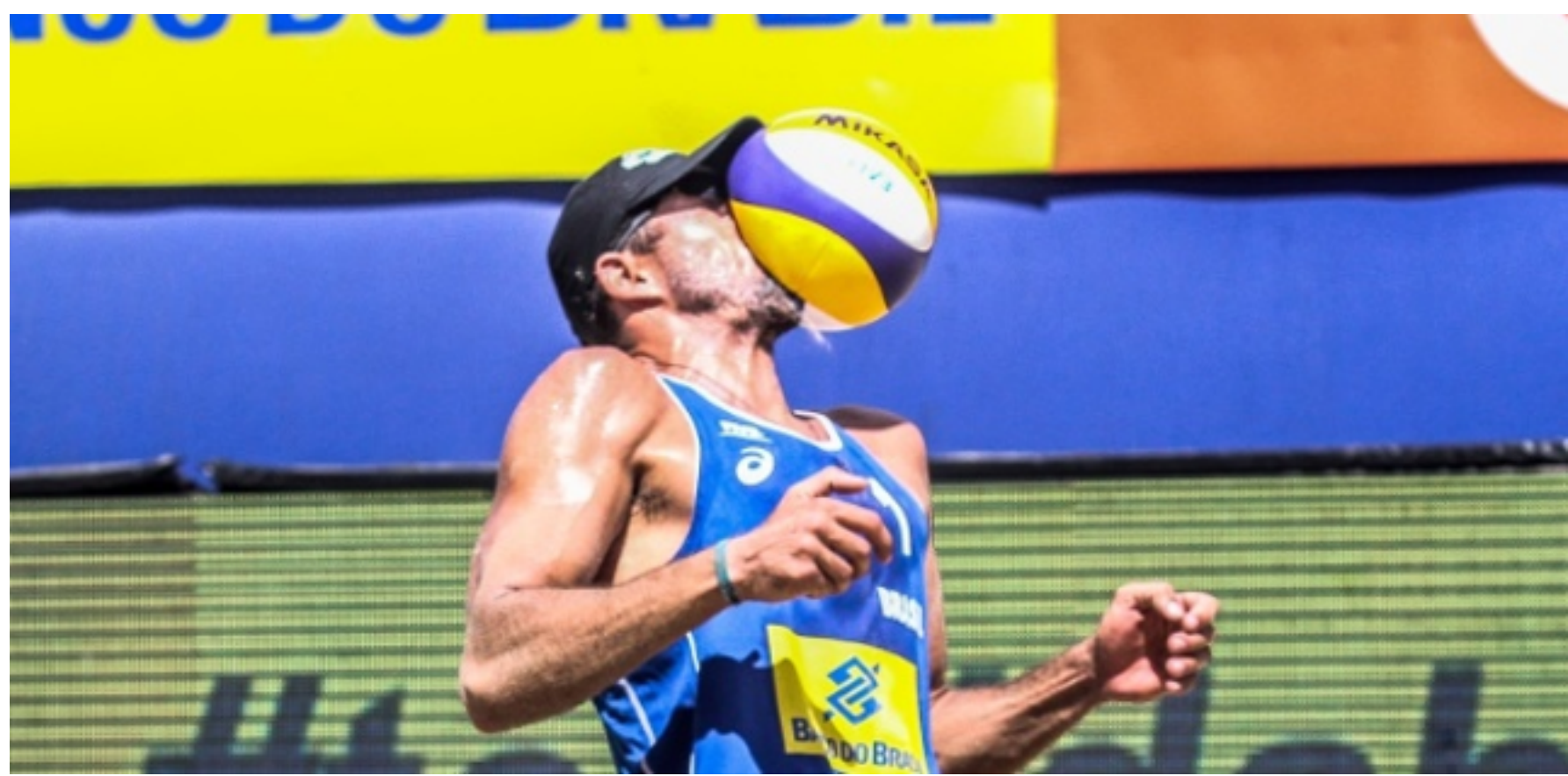


Imagem 03 - deformação dos corpos. Fonte: http://torcedores.com/noticias/2016/05/foto-do-dia-brasileiroleva-bolada-no-rosto-e-tem-oculos-quebrado

Toda colisão terá três momentos distintos: o "antes", o "durante" e o "depois".

No "antes" os corpos encontram-se em movimento de aproximação, rumo a colisão. No "depois", em seu retorno, quase sempre os corpos que possuem propriedades elásticas, se afastarão.

No "durante", no momento da colisão, os corpos se chocam e assim trocam forças de contato, este instante se dá de forma muito rápida, em frações de segundo, aqui definido em $1 / 100$ s ou ou 0,01 segundos, conforme visto na equação relativa ao Teorema de Impulso.

Sabe-se que este intervalo, que se dá em fração de segundos pode ser subdividido ainda em duas etapas menores, conhecidos como deformação e restituição.

As imagens 1 e 2 mostram as deformações dos corpos, neste caso, o rosto do atleta e a bola, neste ínterim de 0,01 segundos, (Valor adotado) a energia cinética ou de movimento dos dois corpos, vai diminuindo e sendo acumulada como energia potencial elástica, e com esta deformação as forças aumentam, se somam. E na restituição, a energia armazenada vai se transformando de volta em energia de movimento, enquanto que os corpos vão restituindo suas formas originais, caso estes possuam propriedades elásticas obviamente.

A colisão da bola contra o rosto do jogador visto nas fotos acima, pode ser considerada parcialmente elástica, com perda de energia e separação dos corpos após o choque.

As fotos demonstram a existência daquilo que a olho nú, não é possível de ser visto, (Aqui definido em 1/100s) que existe uma deformação do rosto, esta confirma a existência da força da bola no rosto do atleta e a deformação da bola demonstra a existência de uma força do rosto contra a bola, conceito utilizado para o cálculo do impacto da bola sobre as barras superiores de sustentação das redes.

Assim tem-se:

198 Joules $/ 0,15 \mathrm{~m}=1320 \mathrm{~N} /(1 \mathrm{~N}=9,80665 \mathrm{Kgf})=134,60 \mathrm{Kgf}$

Ou seja:

\section{A bola ao atingir a barra superior de sustentação da rede em sua extremidade terá uma força peso equivalente a 134,60Kgf.}

\subsubsection{Teorema do impulso}

\section{Análise B:}

Cálculo do impacto da bola contra a barra superior de sustentação da rede, para saber qual o valor da força que a bola causará nesta barra.

Utilizando-se da Lei da Ação e Reação, (Terceira Lei de Newton) a força que a bola causará na barra terá 
o mesmo valor da força que a barra causará na bola.

Considerações estimativas:

1. admitindo-se que a colisão da bola contra a barra tenha uma duração aproximada de $1 / 100 \mathrm{~s}$;

2. que o módulo da velocidade da bola quando colidiu contra a barra era de aproximadamente 108 $\mathrm{km} / \mathrm{h}$, ou seja, $30 \mathrm{~m} / \mathrm{s}$ (condição mais crítica a ser adotada)

3. depois de colidir contra a barra, admite-se que a bola voltará com velocidade (em módulo) de 54 $\mathrm{km} / \mathrm{h}$, ou seja, $15 \mathrm{~m} / \mathrm{s}$, na mesma direção, porém em sentido oposto ao inicial; (adotou-se para velocidade de retorno e perpendicular, a metade do valor da velocidade)

4. tendo-se a massa da bola igual a $440 \mathrm{~g}$, ou seja, 0,44 kg, massa máxima prescrita pela regra oficial para a prática do Futebol de Salão.

Considerou-se para esta estimativa de cálculo que a bola terá velocidade $+15 \mathrm{~m} / \mathrm{s}$ após a colisão com a barra, então antes da colisão, sua velocidade adotada seria de $-30 \mathrm{~m} / \mathrm{s}$. Os sinais opostos das velocidades tratadas como escalares são usados para definir os sentidos opostos de movimento antes e depois da colisão.

Para efeito de cálculo da força média trocada entre os corpos durante a colisão, utilizar-se-á o Teorema do Impulso, para obtenção dos valores médios, ou seja: 


$$
\begin{aligned}
& m=0,44 \mathrm{~kg} \\
& \vec{v}_{2}=15 \mathrm{~m} / \mathrm{s} \\
& \vec{v}_{1}=-30 \mathrm{~m} / \mathrm{s} \\
& \Delta t=1 / 100 \\
& \vec{F}_{m} \mid * \Delta t=m * \Delta \vec{v} \\
& \vec{F}_{m} \mid * \Delta t=m *\left(\vec{v}_{2}-\vec{v}_{1}\right) \\
& \vec{F}_{m} \mid * \Delta t=m *\left[\vec{v}_{2}-\left(-\vec{v}_{1}\right)\right] \\
& \vec{F}_{m} \mid * 1 / 100=0,44 *[15-(-30)] \\
& \vec{F}_{m} \mid=m *\left[\vec{v}_{2}-\left(-\vec{v}_{1}\right)\right] * \Delta t \\
& \vec{F}_{m} \mid=0,44 *[15-(-30)] * 100 \\
& \vec{F}_{m} \mid=0,44 * 45 * 100 \\
& \vec{F}_{m} \mid=1980 \mathrm{~N} \\
& 1980 \mathrm{~N} / 9,80655=201,90 \mathrm{Kgf}
\end{aligned}
$$

Ou seja, a barra de aço vai receber o impacto da bola com a força média de $201,90 \mathrm{Kgf}$ Esta barra lateral e superior foi projetada de forma a não permitir que a bola volte em jogo, sem que o juiz possa vê-la, que eventualmente possa interferir na arbitragem.

Cálculo estimativo: Perito Valmir Chervenko

Por se tratar de um cálculo estimativo, não foram consideradas forças em que uma bola em movimento no ar está sujeita, como forças aerodinâmicas, de arrasto, antiparalelo à velocidade e a sustentação, perpendicular à velocidade, além da tecnologia empregada na bola projetada por cada fabricante e o atrito do ar.

Nem tampouco foram analisadas as possíveis trajetórias que a bola pode imprimir, ou seja, as condições em que a bola pode retornar pela mesma trajetória inicial, direto para o atacante que a chutou ou se a mesma ao se chocar com a superfície circular da trave, qual ângulo e direção, esta poderá assumir.

$\mathrm{Na}$ ausência de informações como valores das velocidades da bola antes e depois da colisão e o valor exato do tempo de colisão, tais dados foram estimados, para fins de obtenção de cálculos ilustrativos, além da necessidade de ser realizado um cálculo levando-se em conta a rigidez do material referente a barra (Tubo) superior de sustentação da rede. 
Ensaios apropriados em Centros Técnicos especializados e cálculos de física aplicada ao futebol devem ser elaborados de forma a confirmar as diretrizes básicas, as quais este autor apresenta neste estudo.

Especificação do material: (NBR 5580:2002 - Classe Leve para tubos pretos)

Tubos verticais da trave, horizontais e requadro inferior DIN 80:

Diâmetro externo de $88,9 \mathrm{~mm} / \mathrm{e}=3,35 \mathrm{~mm} /$ Massa $=7,07 \mathrm{Kg}$

Tubo superior lateral DIN 25:

Diâmetro externo: 33,7mm / e = 2,65mm / Massa $=2,03 \mathrm{Kg}$.

Especificação do material: (NBR 5580:2002 - Classe Média para tubos pretos)

Tubos verticais da trave, horizontais e requadro inferior DIN 80:

Diâmetro externo de $88,9 \mathrm{~mm} / \mathrm{e}=4,0 \mathrm{~mm} /$ Massa $=8,38 \mathrm{Kg}$

Tubo superior lateral DIN 25:

Diâmetro externo: 33,7mm / e = 3,35mm / Massa $=2,51 \mathrm{Kg}$.

Para os casos em que a trave receberá pintura em tinta esmalte sintético, utilizar tabela referente a tubos galvanizados, com pintura de proteção para posterior aplicação de tinta de acabamento.

\section{DEFINIÇÃO CONSTRUTIVA PARA OS FIXADORES DE REDES NA ESTRUTURA TUBULAR DA TRAVE}
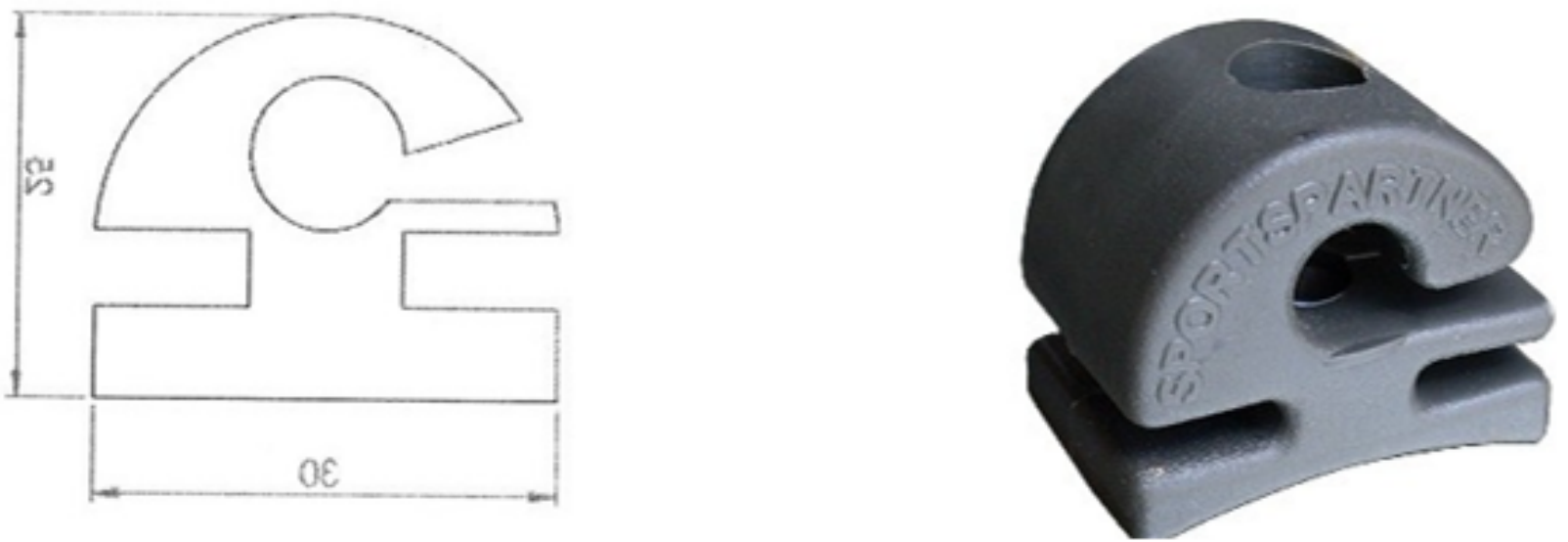

Figura 19 - Detalhe construtivo para peças em PVC para fixação de rede da trave. Fonte: SPORT PARTNER - Distribuição e Fabrico de Equipamentos Esportivos

Os fixadores de redes deverão obter as seguintes características, a saber:

- Peças em PVC, material resistente, porém maleável;

- Necessário que o mesmo tenha cantos arredondados para evitar lesões;

- A distância recomendada entre as peças será de $200 \mathrm{~mm}$. 

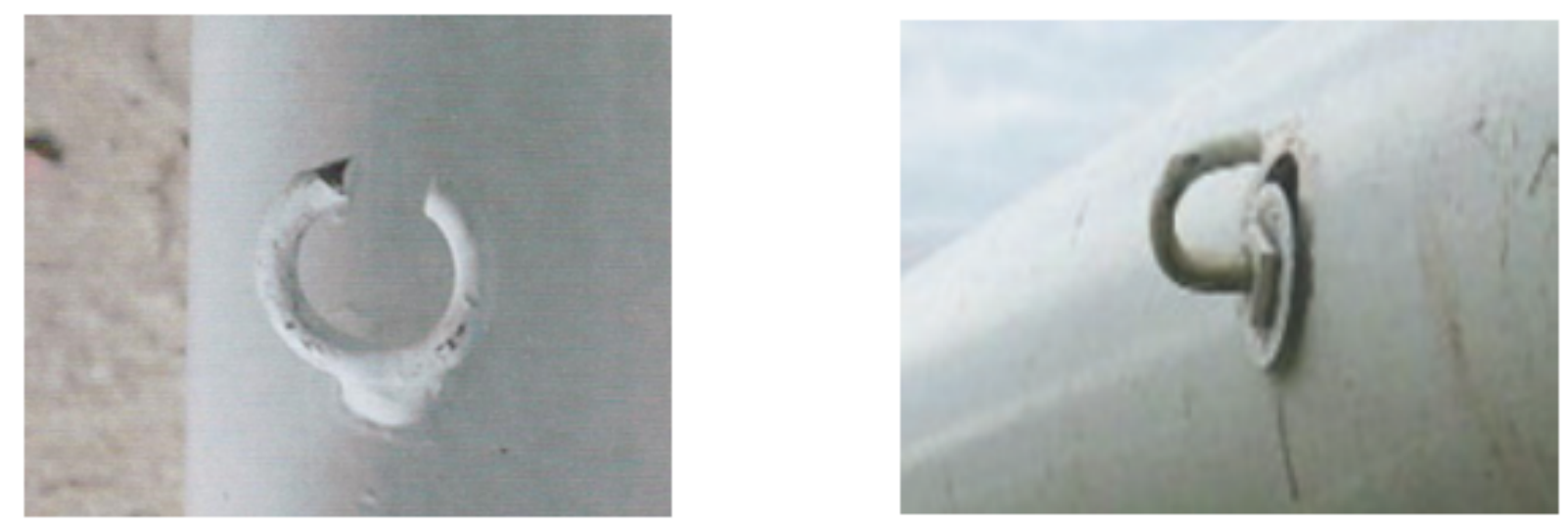

Imagem

04 - Gancho comumente encontrado nas traves. Fonte: HARROD UK LIMITED - Setting the Standart Leading the Field

Estes elementos causam acidentes em diversas partes dos membros superiores do corpo, na pratica de subir na trave, seja para brincadeiras, apoiar para se exercitar ou comemoração do gol ou mesmo na instalação de rede, as partes mais afetadas são as mãos, pulsos, braços e principalmente dedos da mão que contenham aliança ou anel, o mesmo fica preso no gancho metálico tendo como consequência o seu arranchamento e perda do dedo, pois neste tipo de acidente não há como restituir com cirurgias.

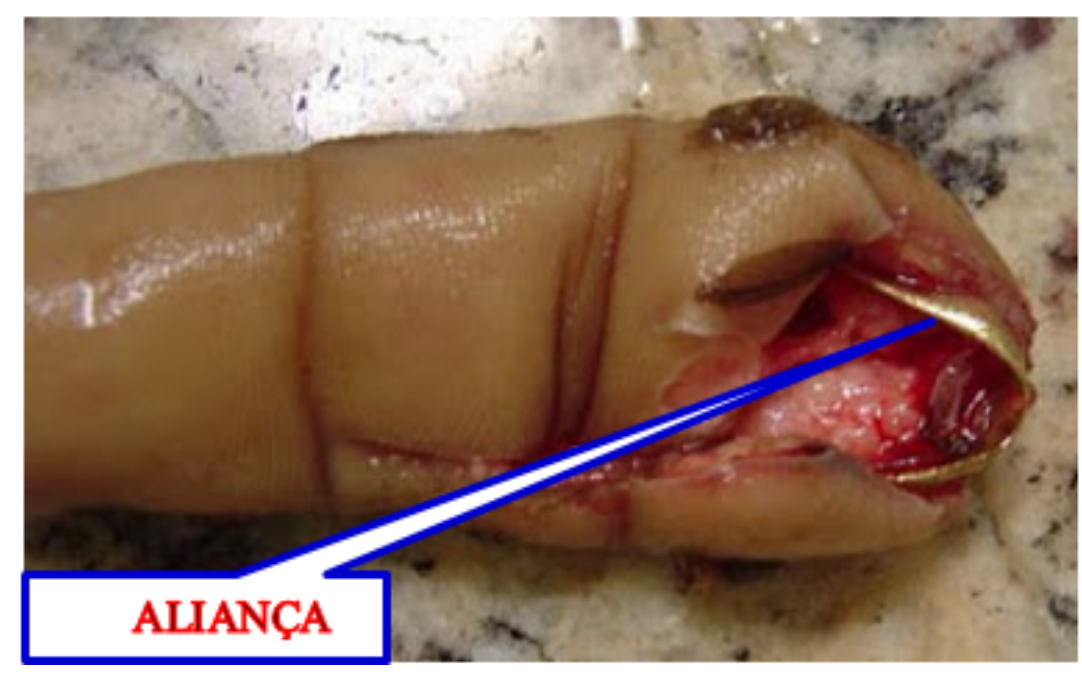

Foto 01 - Acidente com dedo preso no

gancho da trave de futebol 


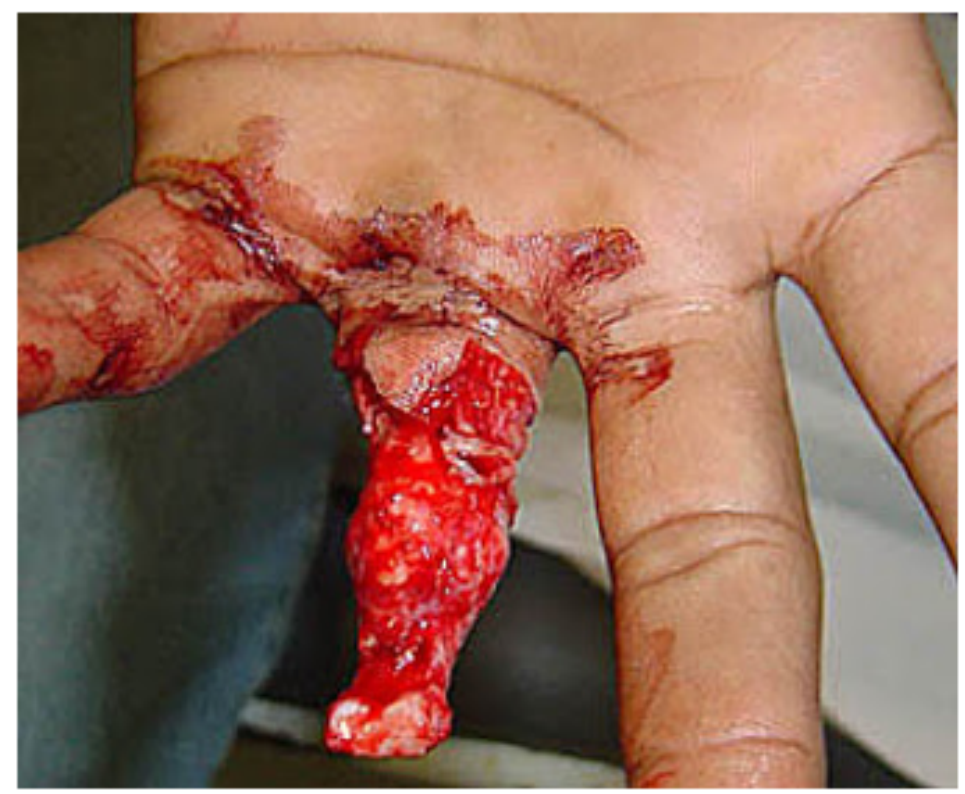

Foto 02 - Perda do dedo por uso inadequado de ganchos em traves de futebol. Fonte das fotos 01 e 02: http://mortehumana.blogspot.com.br/2008/08/dedoreemplantado.html

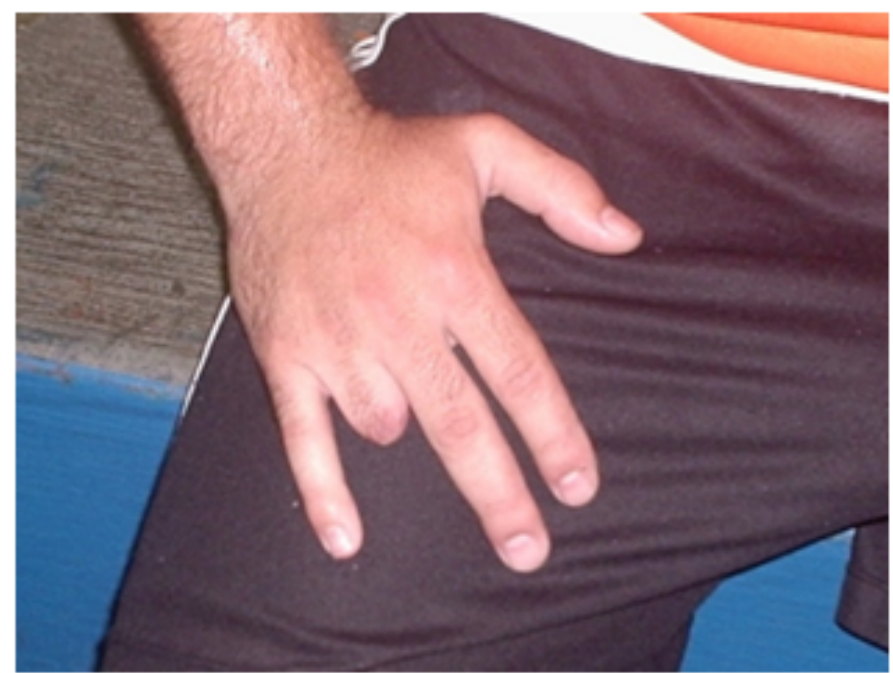

Foto 3 - Resultado da perda de dedo mediante acidente com ganchos metálicos na trave. Foto: Do Autor, conforme pesquisa em quadras esportivas

\section{RECOMENDAÇÕES GERAIS RELATIVAS A SEGURANÇA DAS TRAVES}

Mesmo após correção das condições de segurança deste equipamento, cartazes deverão ser colocados em locais estratégicos no espaço esportivo com os seguintes dizeres:

- NUNCA SUBA OU SE PENDURE NA TRAVE, A TRAVE PODE TOMBAR E CAUSAR GRAVE LESÃO OU MORTE;

- NÃO MANUSEAR TRAVES SOLTAS EM DIAS DE VENTOS FORTES;

- EM DIAS DE IMINÊNCIA DE CHUVAS OU RAIOS, FUJA DAS QUADRAS E CAMPOS ABERTOS, PERIGO DE RAIOS ATINGIREM USUÁRIOS. (Atender norma francesa NF C 17

- 102 July 1995 e Norma Portuguesa NP 4426:2013 para implantação de sistema de para-raios 
específicos para áreas externas, como referência, os fabricados pela Indelec - La Foudre Apprivoisée - Unidade Sorocaba-SP)

\section{CARRO TRANSPORTADOR PARA TRAVES DE FUTSAL}

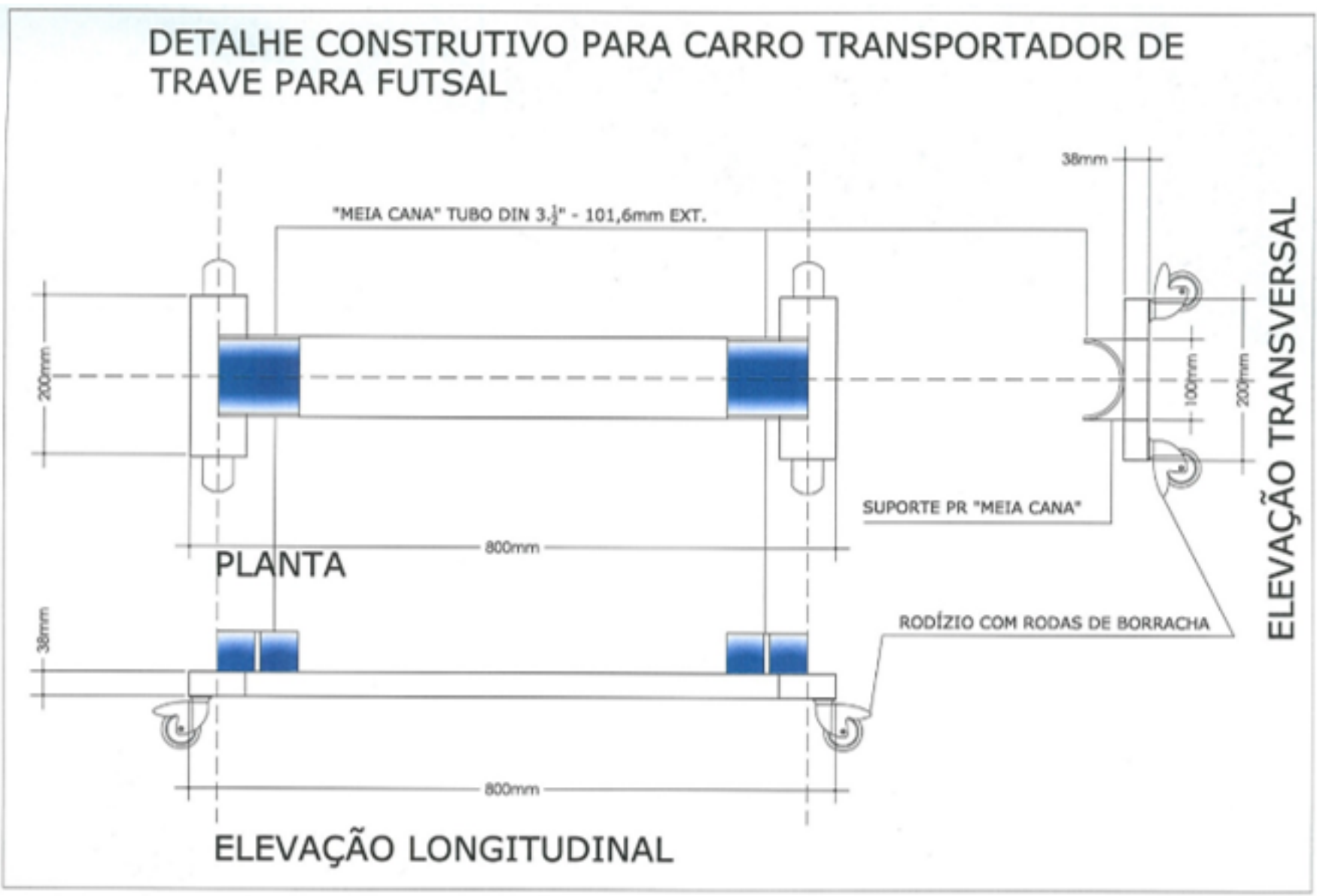

Figura 20 - Projeto modelo para carro transportador de traves. Fonte: Projeto preliminar do Autor

O carro para transporte de traves de Futsal deverá ter estrutura em metal com tratamento anticorrosivo.

Os rodízios deverão ser multidirecionais e revestidos com borracha de alta resistência, de forma que possa permitir o deslocamento da trave com segurança e minimizar riscos de lesões e evitar acidentes.

OBS:

Para utilização de consumíveis na soldagem dos tubos, poderão ser adotados os sistemas do tipo Mig (Mag) ou Tig, ambos devem ser realizados em conformidade com as normas para materiais de utilização conforme norma American Welding Society - AWS e as normas da ABNT pertinentes ao tema, além da NR 18 - Condições de ambiente de trabalho na indústria da construção - 18.11 Operações de Soldagem e Corte a Quente, NR 34 - Condições e meio ambiente de trabalho na indústria da construção e reparação naval e NBR 7678 - Segurança na Execução de Obras e Serviços de Construção.

\section{TESTES EM TRAVES DE FUTSAL CONFORME NORMA PORTUGUESA NP EN 749}




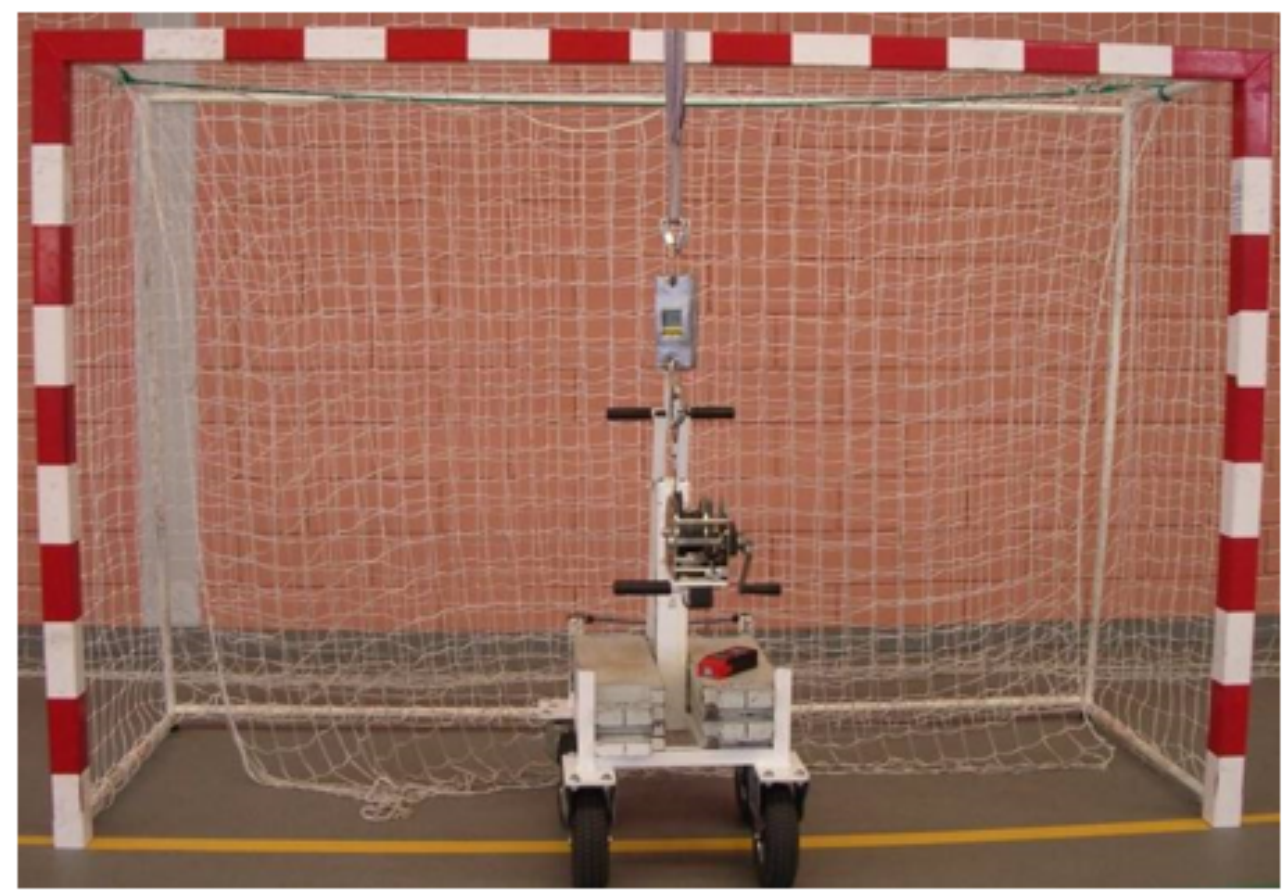

ensaio de resistência. Fonte: Engo José Manuel Viegas - Lemon Safe (Pt)

Figura 21 - Traves de futsal:

É aplicada ao meio da trave uma força vertical de 180 daN durante 60 a 70 segundos.Uma deflexão permanente é tolerada se não exceder os $10 \mathrm{~mm}$.

Este ensaio refere-se à segurança dos usuários nos recintos esportivos, deve-se acrescentar aspectos a serem observados como: ruídos e inspeção visual de rupturas de soldas e corrosão ao longo das balizas.

A unidade daN é uma unidade de força e significa decaNewton. O prefixo deca (da) significa 10. Portanto, um decaNewton (1 daN) é igual a dez Newtons $(10 \mathrm{~N})$, que é igual a 1,0197 $\mathrm{kgf}(\mathrm{kgf}$-> quilograma-força).

Como o Newton $(\mathrm{N})$ é a unidade de força do Sistema Internacional de Unidades (SI), mas não é popular como o Quilograma-força (kgf), está tornando-se mais frequente o uso do decaNewton (daN), pois é uma forma de usar uma unidade derivada do Sistema Internacional e que equivale a aproximadamente $1 \mathrm{kgf}$.

Logo: $1 \mathrm{kgf}=9.80665 \mathrm{Newton}=9.81 \mathrm{~N}$

$\mathrm{ou}$

0.980665decanewton

Portanto: $1 \mathrm{daN}=1 / 0.980665=1.01972 \mathrm{kgf}$

Assim sendo, temos: $180 \mathrm{daN}$ x $1.01972=183.54 \mathrm{kgf}$

10. TABELAS PARA BASQUETEBOL CONFORME NP EN 1270 - EQUIPAMENTOS DE BASQUETEBOL 


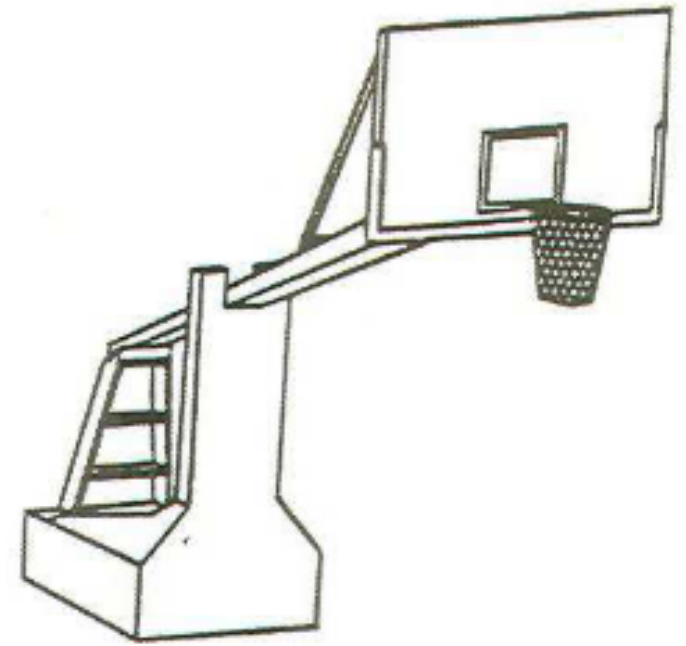

extensão de $3250 \mathrm{~mm}$ a $2250 \mathrm{~mm}$ - Tipo 1

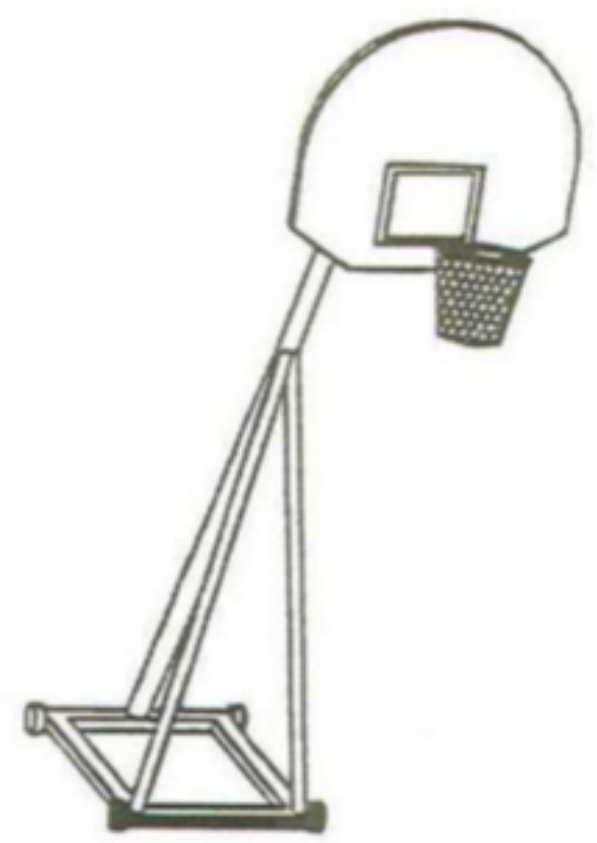

extensões - Tipo 2
Figura 22 - Equipamento auto estável com

Figura 23 - Equipamento auto estável com outras 


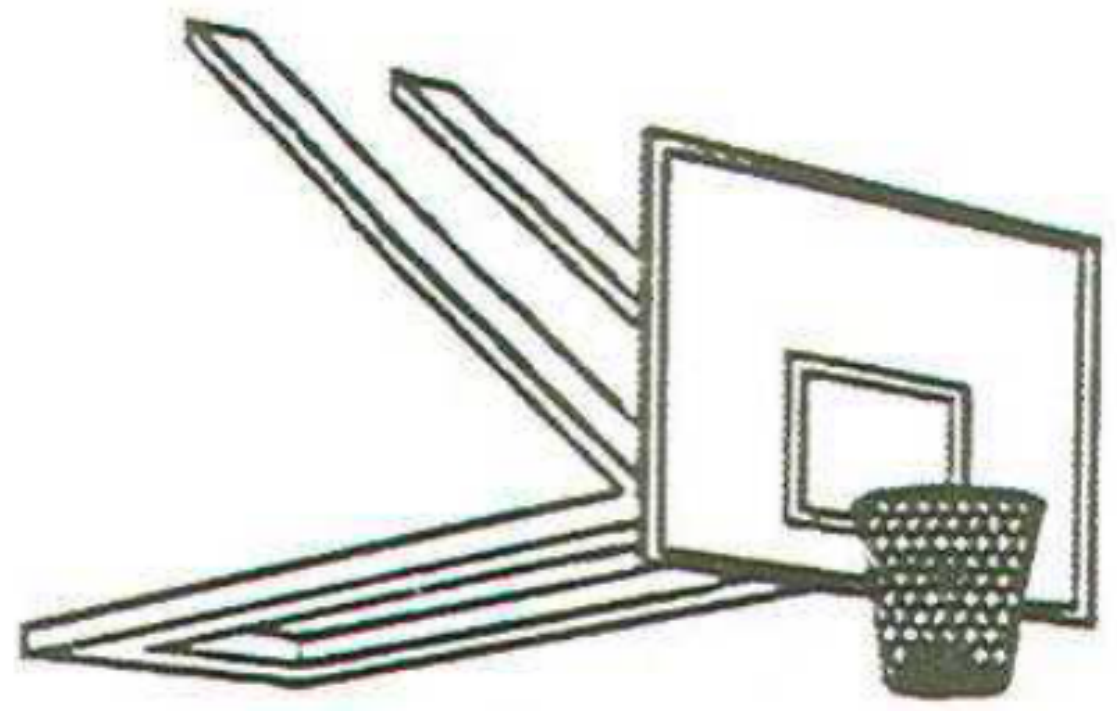

Equipamento rebatível - Tipo 3

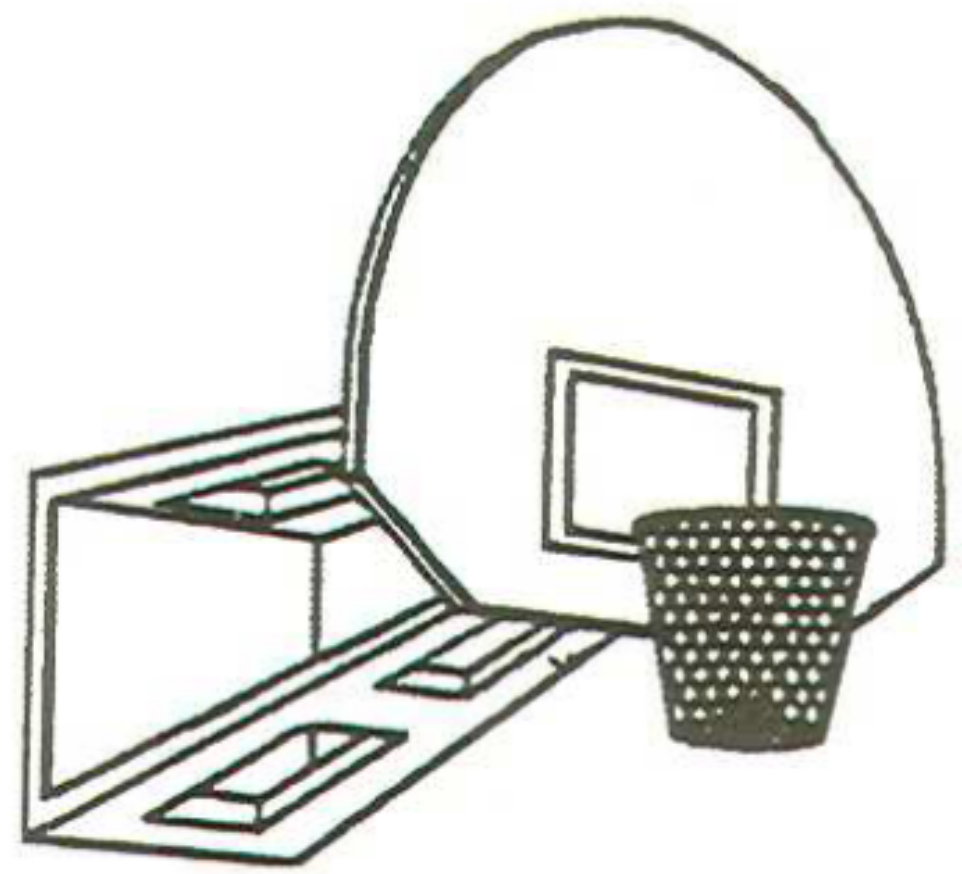

à parede; - Tipo 4 


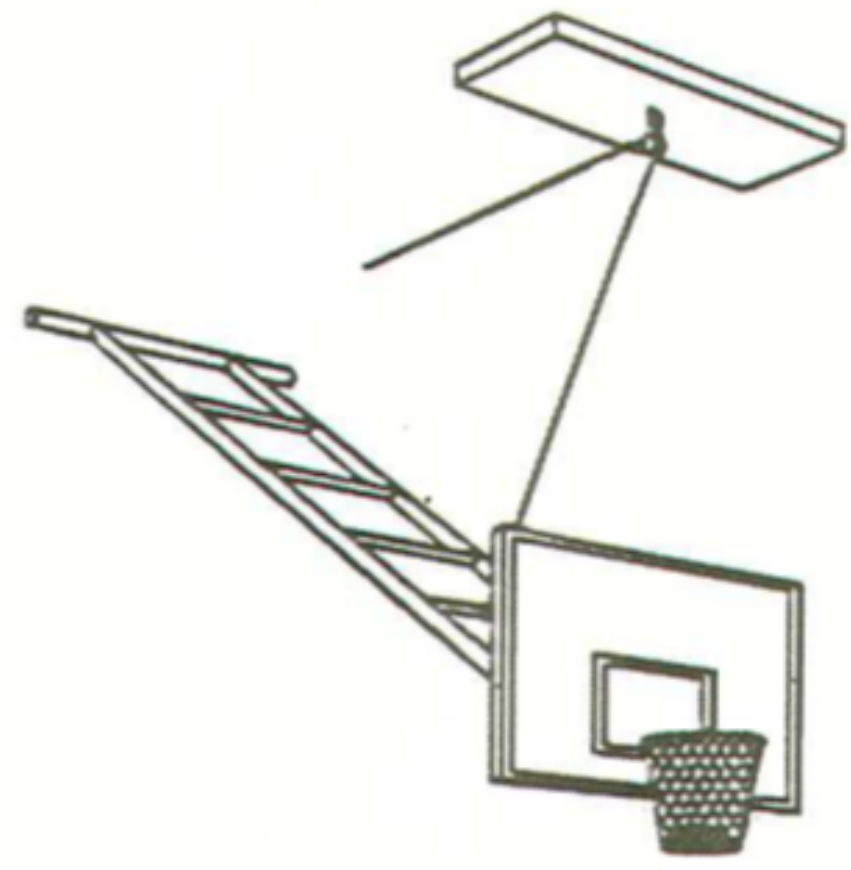

Montado no teto - Tipo 5

Figura $26-$ Equipamento

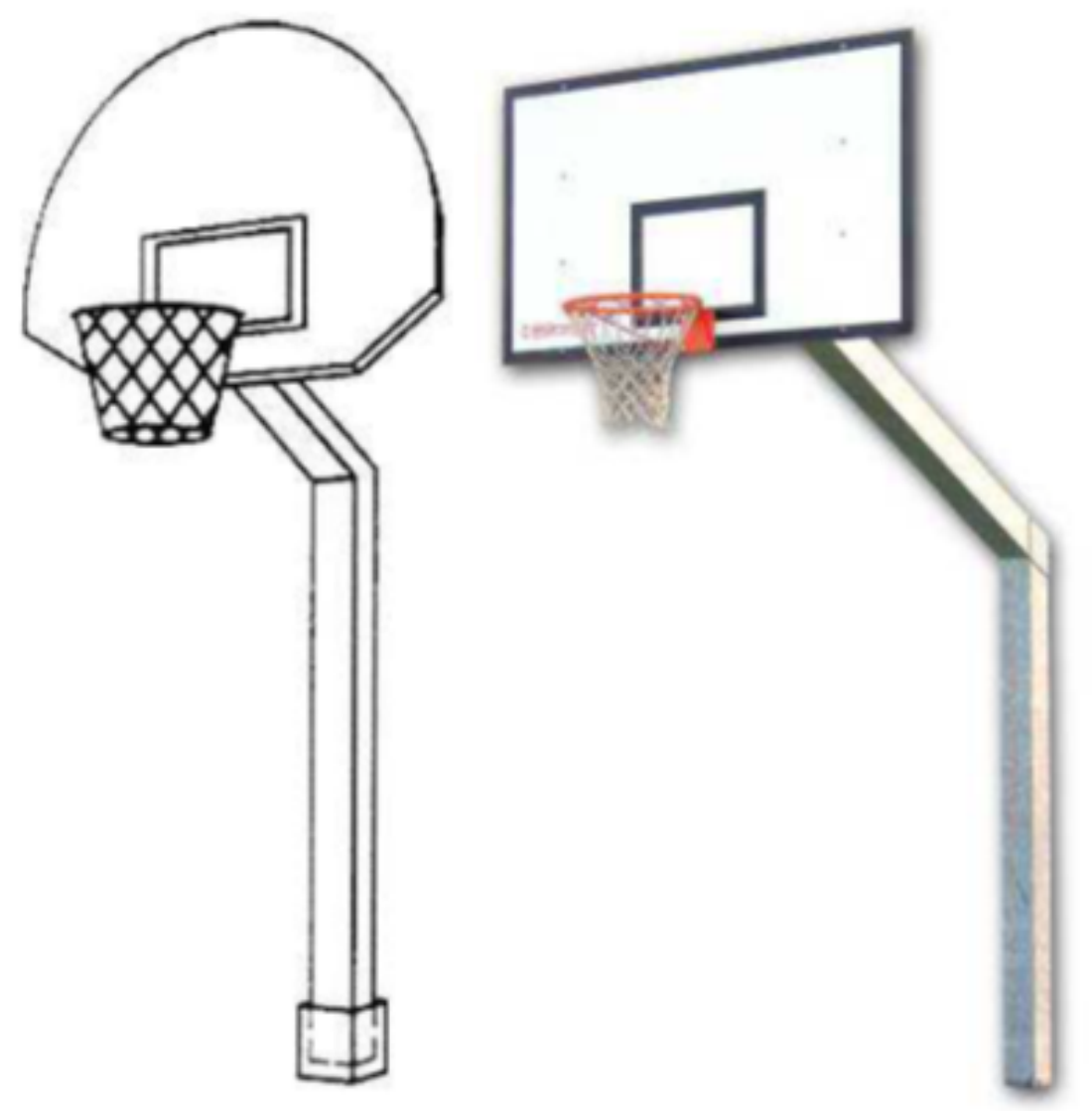

Figura 27 - Equipamento 
removível do piso - Tipo 6 (Poste de concreto ou de aço)

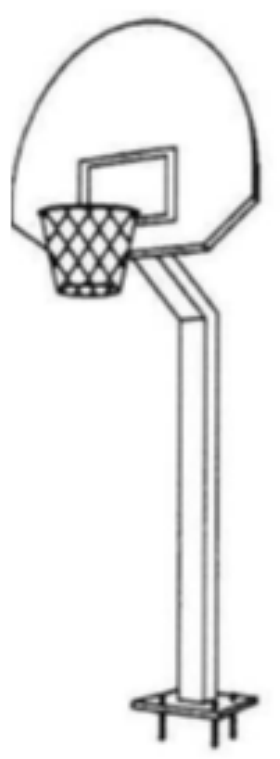

concreto ou de aço)

Figura 28 - Equipamento fixo no piso - Tipo 7 (Poste de

Equipamento do Tipo 8 prescrito pela norma NP EN 1270 deve ser regulável em altura de $2600 \mathrm{~mm}$ a $3050 \mathrm{~mm}$.

Na pesquisa dos locais vistoriados, são mais presentes os equipamentos do Tipo 1,2 5 e 7.

Sendo que os equipamentos do Tipo 1 devem receber o sistema de fixação não permanente além de contrapeso no braço do equipamento;

Nos equipamentos do Tipo 2, receber sistema de fixação não permanente descrito neste estudo;

No equipamento 5, verificação severa nas condições de cabos de aço e seus acessórios além de checar o sistema de fixação junto à parede;

E nos equipamentos do Tipo 7, aplicar os ensaios relatados neste estudo, além de checar as condições estruturais do concreto ou do aço, utilizados para sustentação do conjunto cesta e tabela.

\section{DEFINIÇÃO CONSTRUTIVA DE FIXAÇÃO NÃO PERMANENTE PARA TABELAS DE BASQUETEBOL}

11.1 Sistema de fixação para tabelas de basquetebol do Tipo 1 e 2 


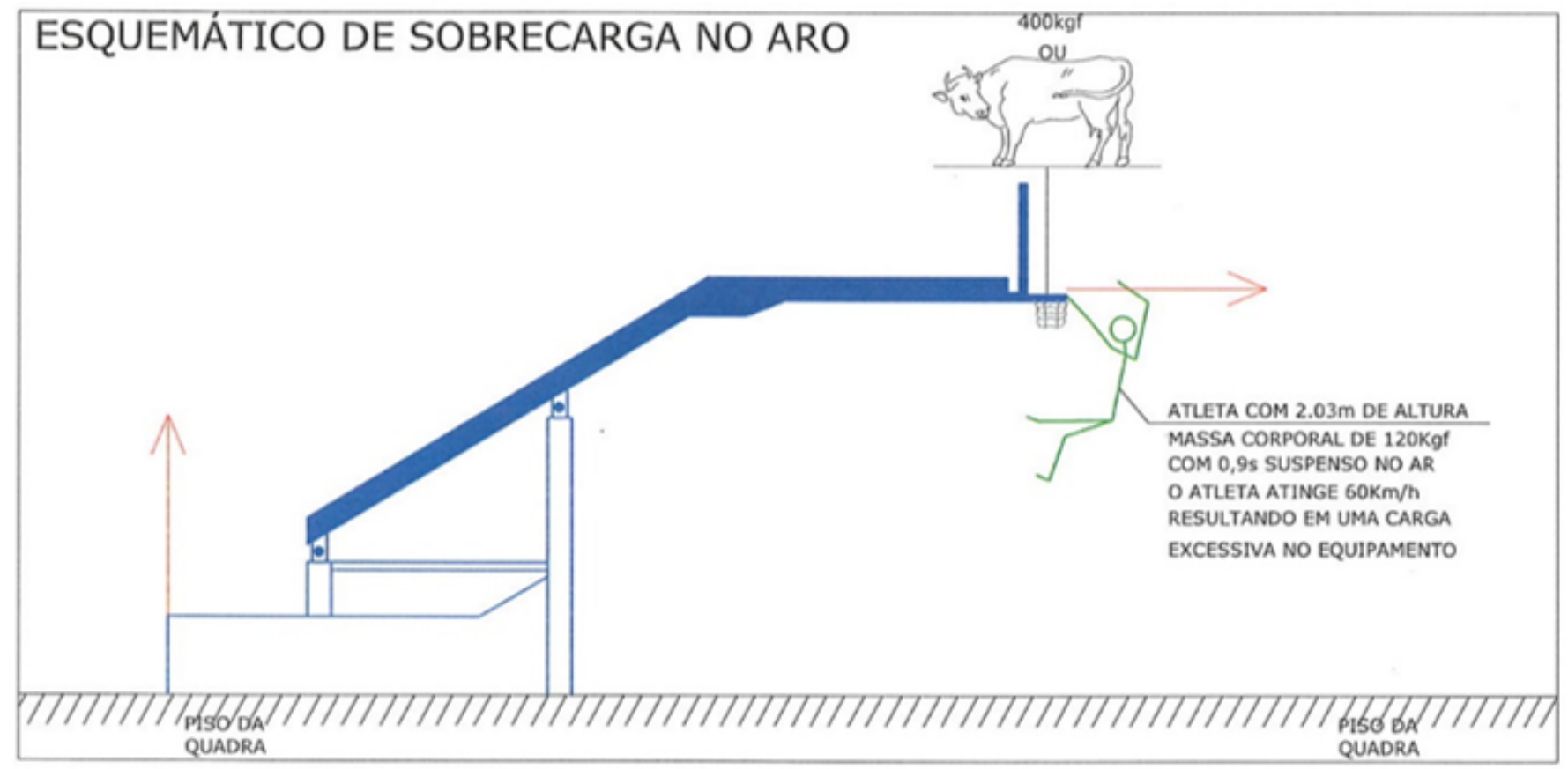

Figura 29 - Ilustração esquemática de uma tabela móvel Tipo 1 e 2, em repouso e a sobrecarga possível, sobre o equipamento no ato de uma "enterrada". Fonte: Núcleo de Auto Rendimento Esportivo (NAR) Dr. Irineu Loturco - Desenho do Autor

Segundo Irineu Loturco, diretor do Núcleo de Auto Rendimento Esportivo (NAR), ensaios com um atleta brasileiro de 1,92m de altura e massa corporal de $92 \mathrm{Kgf}$, utilizando sensores de movimento que mapeiam as ações e a força que este gera durante uma enterrada, mostraram os seguintes resultados para resistência de tabelas:

- Ao saltar, em 0,9 segundos no ar, o jogador atinge a tabela a $60 \mathrm{Km} / \mathrm{h}$ e a energia dissipada sobre o aro é equivalente a $300 \mathrm{Kgf}$. Percebe-se que a massa corporal do atleta foi multiplicada por 3,26 vezes no momento do impacto, ou seja, a tabela tem que suportar $300 \mathrm{Kgf}$, no mínimo, no momento da enterrada.

- No caso de um atleta Americano com massa corporal de $120 \mathrm{Kgf}$ e 2,03 de altura, por exemplo, o impacto seria equivalente a $400 \mathrm{Kgf}$, implicando em maiores cuidados com a segurança. 


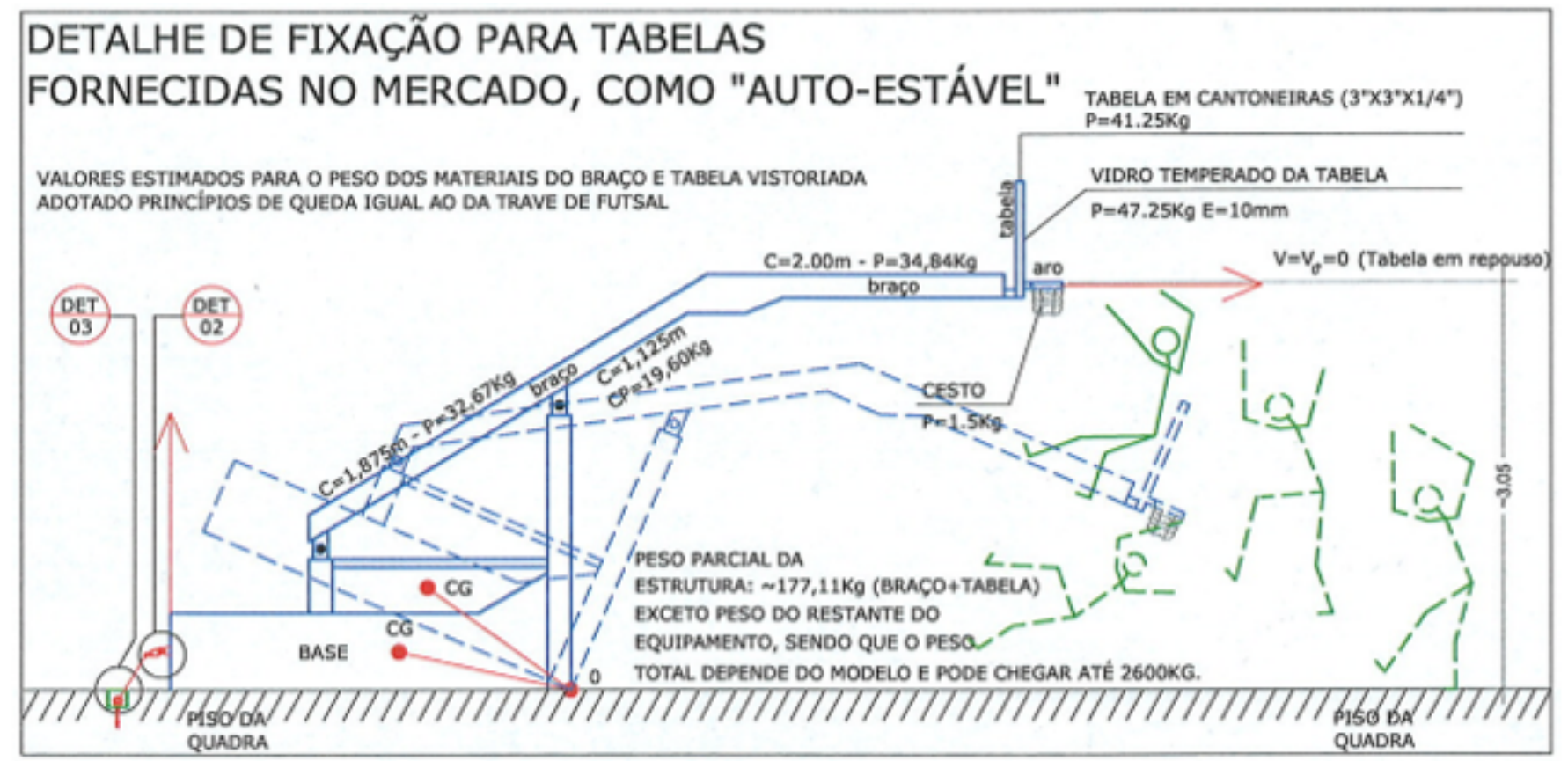

Figura 30 - Fixação a ser realizada na parte posterior central do equipamento. Fonte: Núcleo de Auto Rendimento Esportivo (NAR) - Dr. Irineu Loturco - Desenho do Autor

Para uso desta opção, (Det. 02 e 03) o bloco de fundação deverá suportar a sobrecarga de reação do equipamento, assim como os seus acessórios também devem suportar a sobrecarga do equipamento quando em situação de desestabilização.

\section{DEFINIÇÃO CONSTRUTIVA PARA SE EVITAR O PENDULO DA TABELA DE BASQUETEBOL}

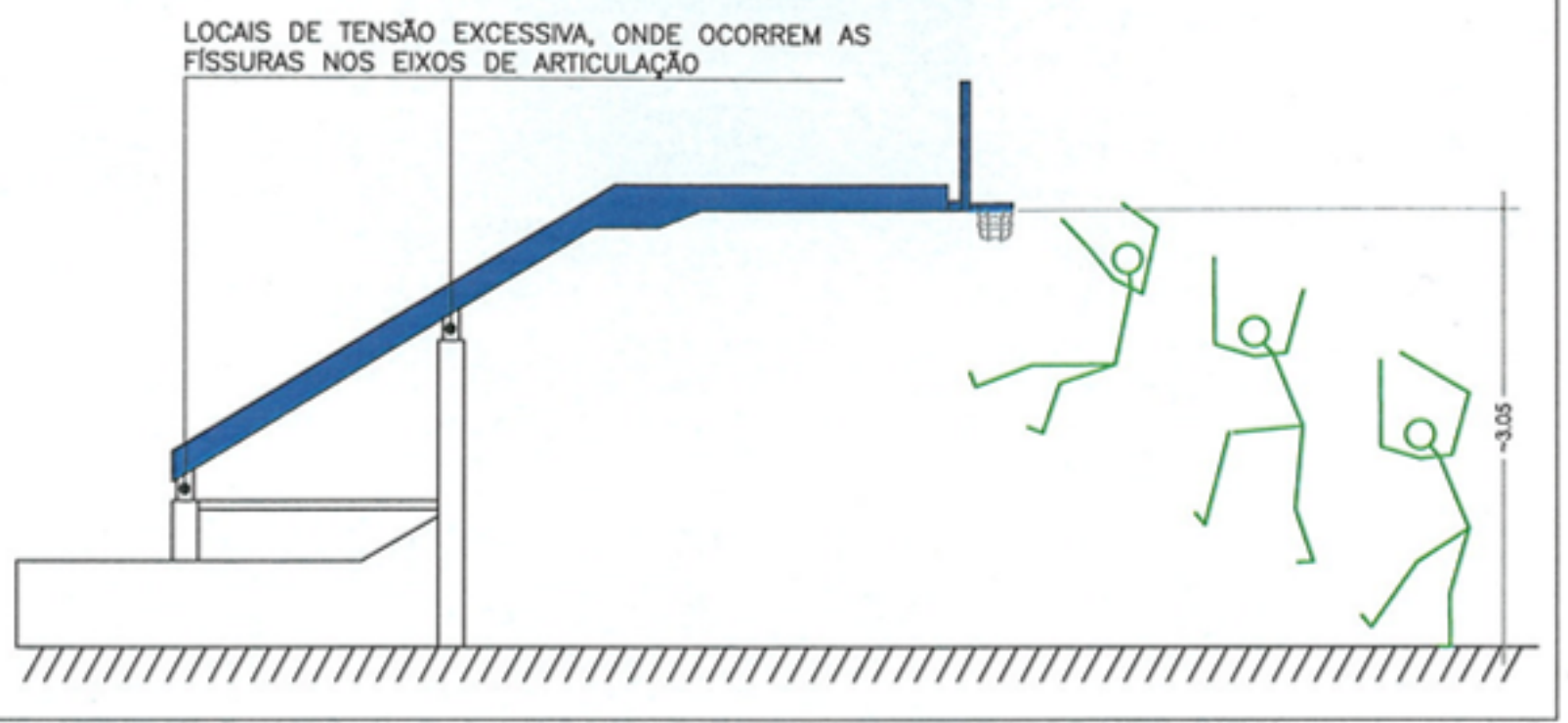

Figura 31 - Ilustração esquemática de uma tabela móvel tipo 1 e 2, em repouso e a sobrecarga possível 
sobre o corpo do usuário ou atleta. Fonte: Desenho do Autor

O ATLETA COM O BRAÇO PRESO OU NAO NO CESTO, O TRAUMA OCORRERA DA MESMA FORMA

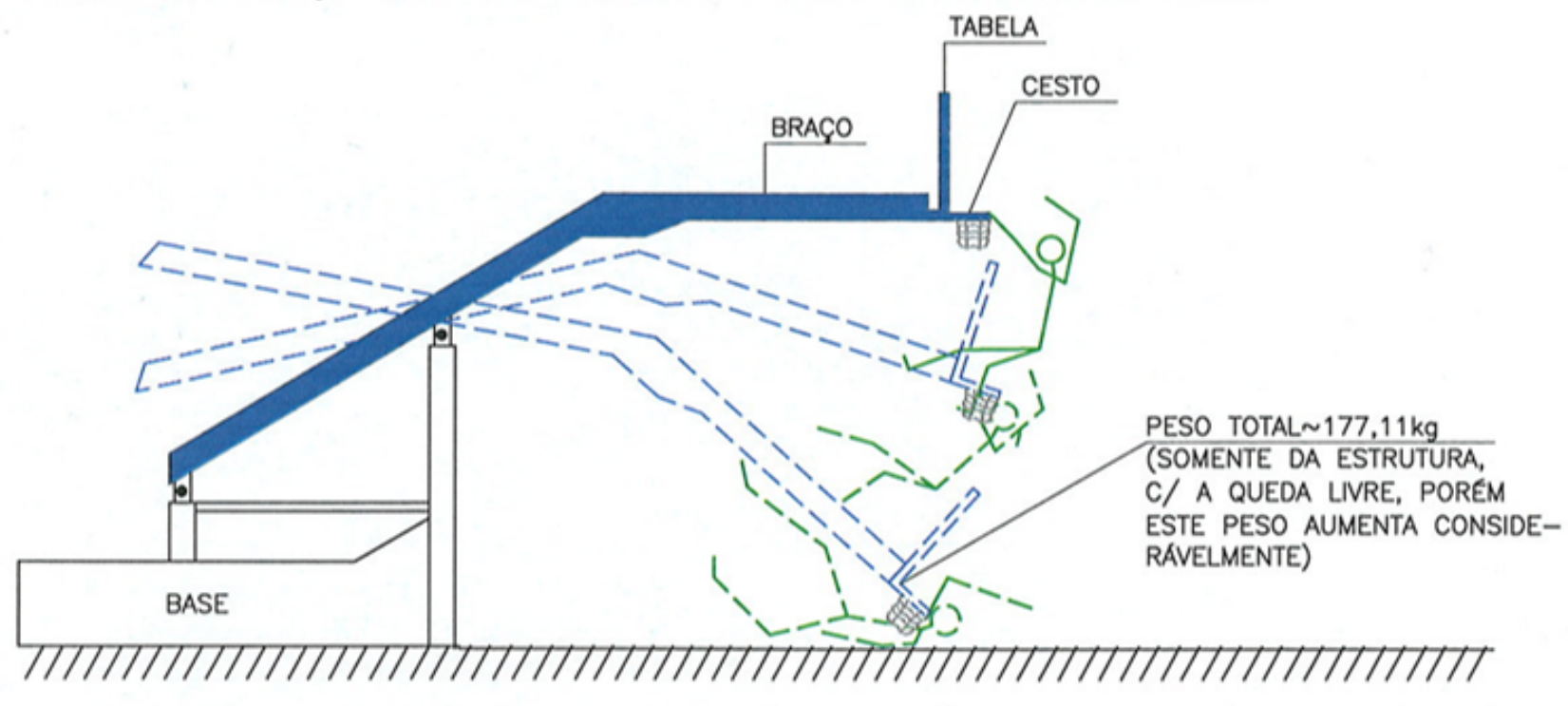

Figura 32 - Ilustração esquemática de uma tabela móvel tipo 1 e 2, em repouso e a sobrecarga possível sobre o corpo do usuário ou atleta, quando em movimento. Fonte: Desenho do Autor

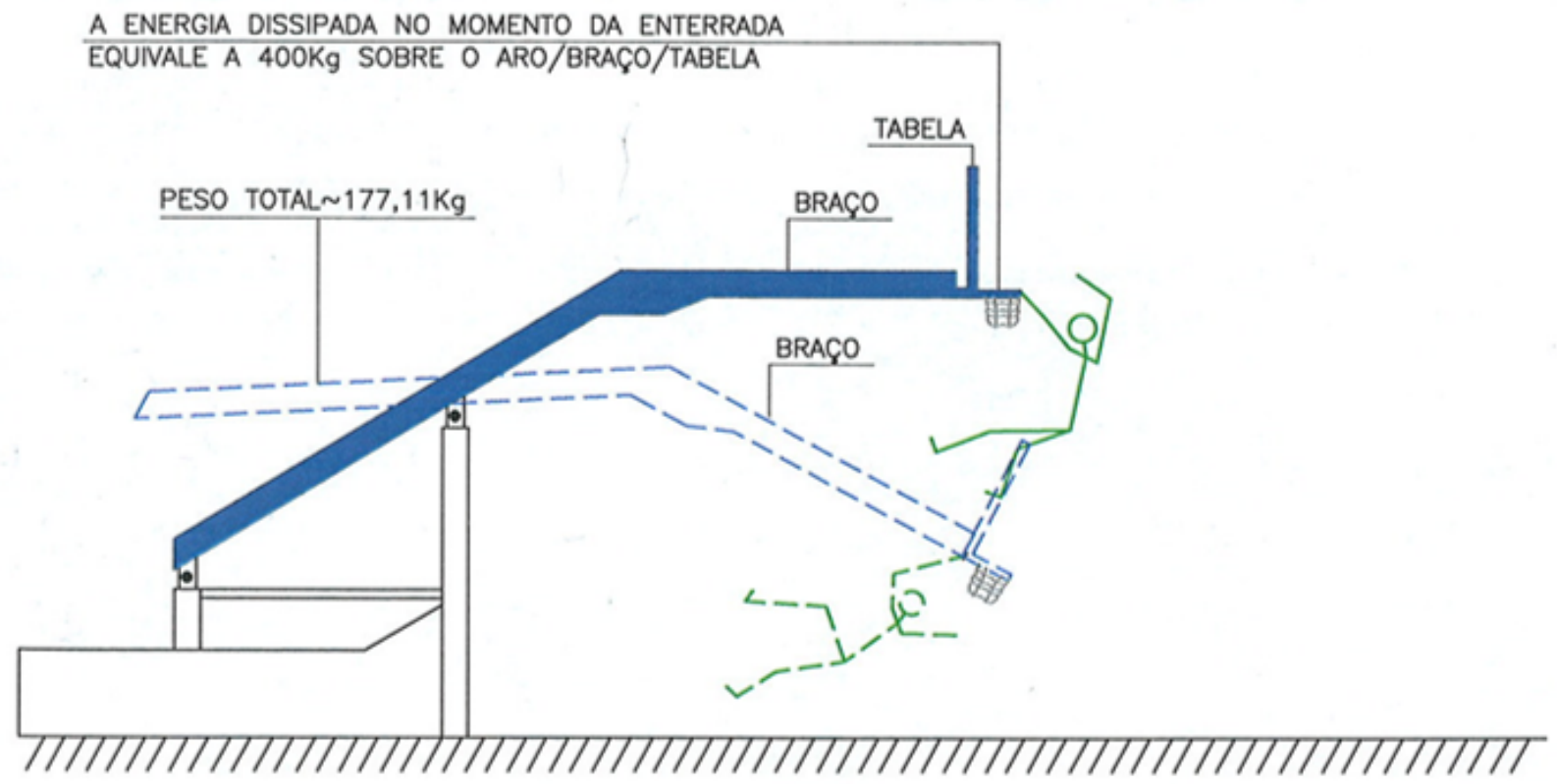

Figura 34 - Ilustração esquemática de uma tabela móvel tipo 1 e 2, em repouso e a sobrecarga possível sobre o corpo do usuário ou atleta. Fonte: Desenho do Autor 


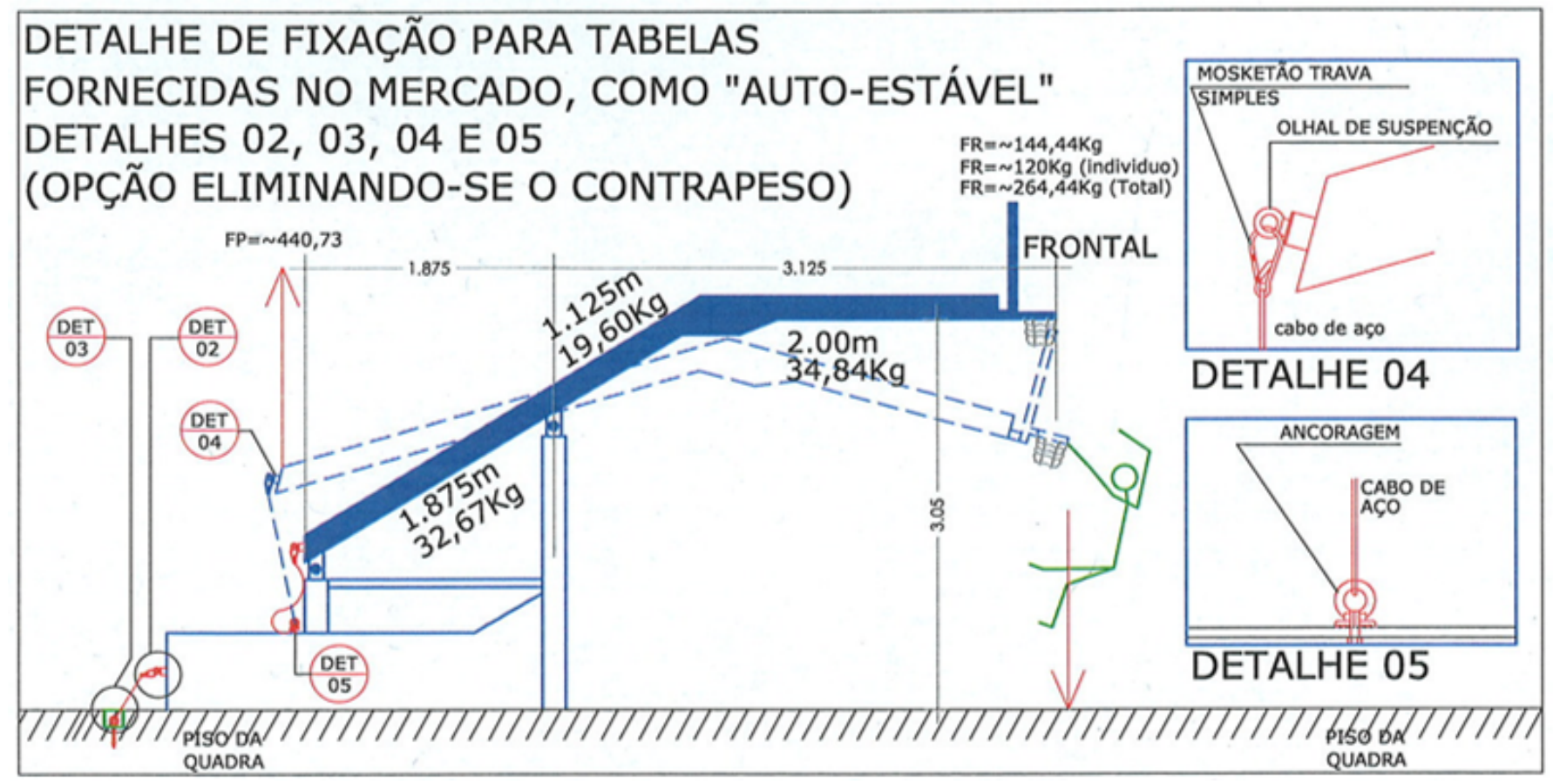

Figura 33 - Ilustração esquemática de uma tabela móvel tipo 1 e 2, em repouso e a sobrecarga possível sobre o corpo do usuário ou atleta, quando em movimento causado por falha no sistema do equipamento, porém definido na Norma Regulamentadora $\mathrm{n}^{\circ}$ 12, do Ministério do Trabalho e Emprego, a obrigatoriedade de dispositivos de segurança previstos neste estudo e formalizados pelo princípio da Falha Segura. Fonte: Desenho do Autor

Para a opção do uso destes dispositivos de segurança (Det. 04 e 05) a serem instalados na parte posterior do equipamento, o cálculo deverá contemplar a sobrecarga com folga, de modo a estabilizar o braço da tabela, além do cabo de aço e demais acessórios suportarem esta carga. 


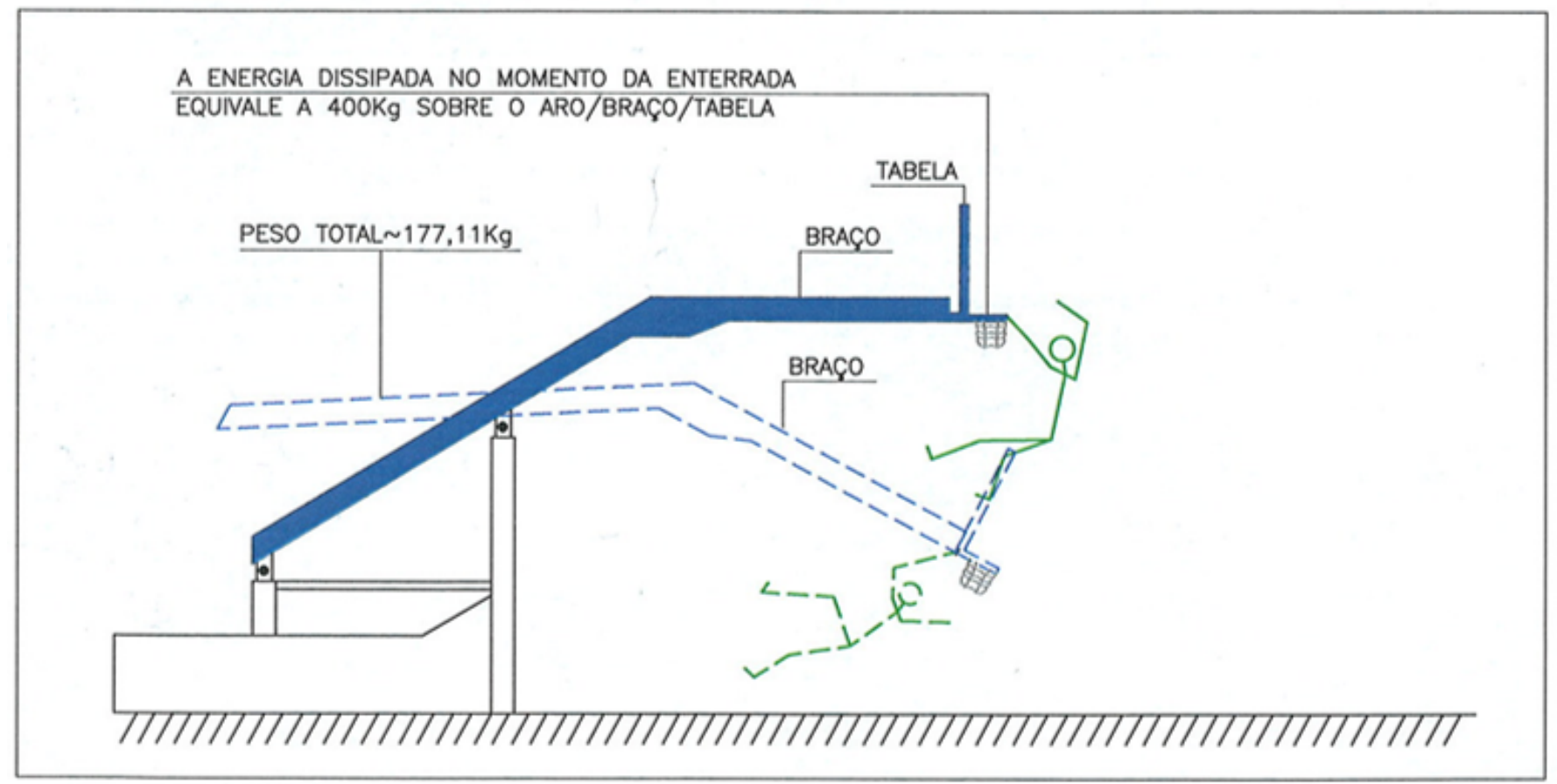

Figura 34 - Ilustração esquemática de uma tabela móvel tipo 1 e 2, em repouso e a sobrecarga possível sobre o corpo do usuário ou atleta. Fonte: Desenho do Autor

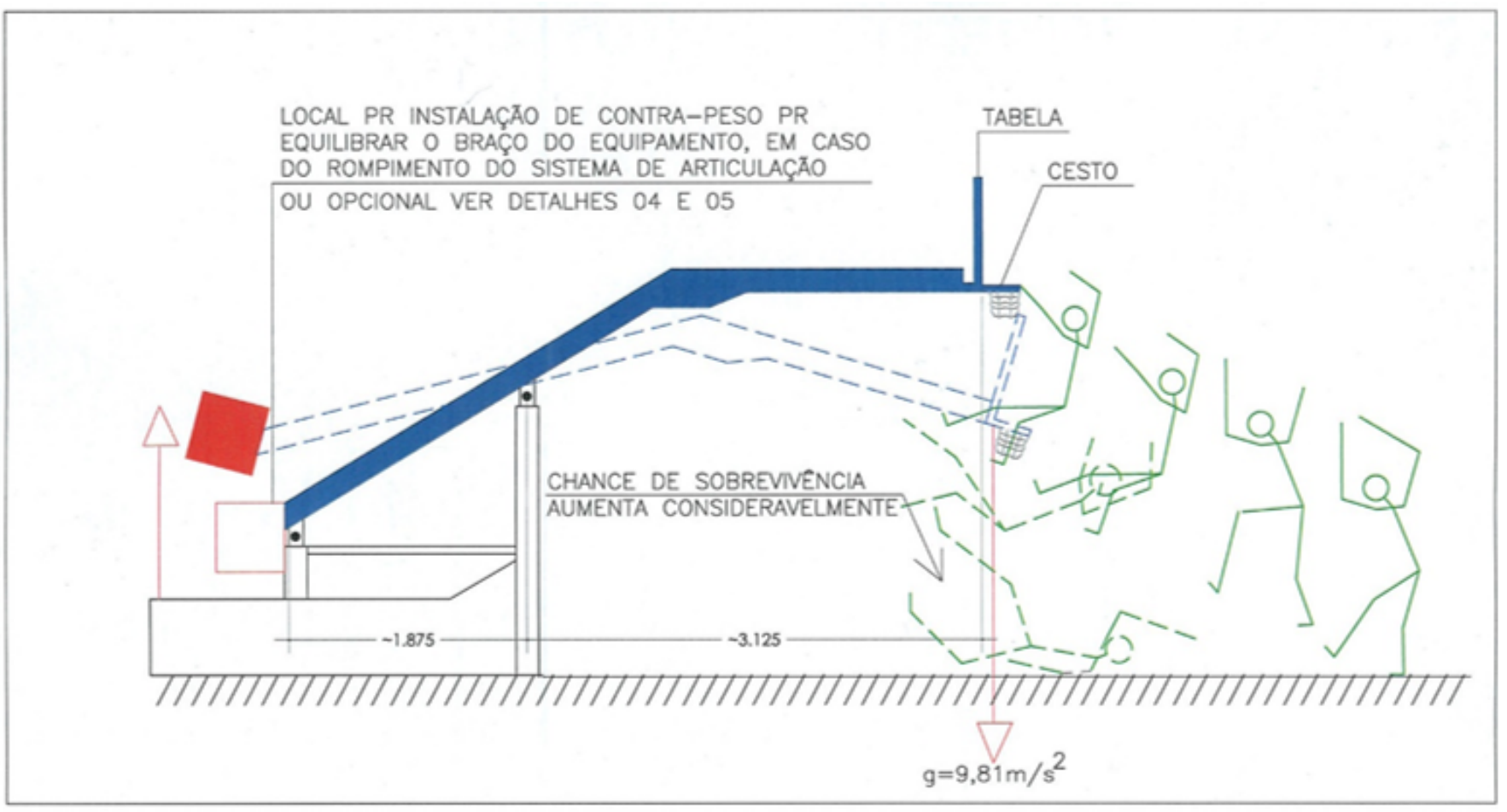

Figura 35 - Ilustração esquemática de uma tabela móvel tipo 1 e 2, em repouso e a sobrecarga possível sobre o corpo do usuário ou atleta. Fonte: Desenho do Autor

Para a opção do contrapeso, o cálculo deverá levar em consideração as seguintes premissas: 
O pré-cálculo foi elaborado para a tabela modelo com dimensões vistas na Figura 35, a saber:

FR = Peso do braço acrescido do peso da tabela, vidro temperado e cesta, igual a 144,44Kg, logo seu peso deve ser convertido em massa, sendo:

$144,44 \mathrm{~kg} \times 9,81 \mathrm{~m} / 2=1.416,95 \mathrm{~N}$

$\mathrm{FR}=1.416,95 \mathrm{~N}$

$\mathrm{FP}=\mathrm{x}$

$\mathrm{bP}=1,875 \mathrm{~m}$

$\mathrm{bR}=3,125 \mathrm{~m}$

Logo: FP x bP = FR x bR

FP $\times 1,875 \mathrm{~m}=1.416,95 \mathrm{~N} \times 3,125 \mathrm{~m}$

$\mathrm{FP} \times 1,875 \mathrm{~m}=4.427,98 \mathrm{~N}$

$\mathrm{FP}=\underline{4.427 .95 \mathrm{~N}}$

$1,875 \mathrm{~m}$

$\underline{\mathrm{FP}}=2.361 .59 \mathrm{~N}$ ou $240.88 \mathrm{Kgf}$

Esta será a força de potência para manter o equilíbrio do braço do equipamento, porém acrescenta-se a massa de um indivíduo de $120 \mathrm{~kg}$ para que seja considerado a somatória da massa do atleta pendurando na cesta.

Logo: FP x bP = FR x bR

FP $\times 1,875 \mathrm{~m}=1.416,95 \mathrm{~N}+(120,00 \times 9,81 \mathrm{~m} / 2) 1.177,20 \mathrm{~N}=2.594,15 \mathrm{~N}$

$\mathrm{FP} \times 1,875 \mathrm{~m}=2.594,15 \mathrm{~N} \times 3,125 \mathrm{~m}$

FP $x 1,875 \mathrm{~m}=8.106,71 \mathrm{~N}$

$\mathrm{FP}=\underline{8.106 .71 \mathrm{~N}}$

$1,875 \mathrm{~m}$

Onde:

$1 \mathrm{kgf}=9.80665 \mathrm{~kg} * \mathrm{~m} / \mathrm{s}^{2}=9.81 \mathrm{~N}$

$1 \mathrm{~N}=1 / 9.80665 \mathrm{kgf}=0,101971621 \mathrm{kgf}$

$1 \mathrm{~N}=0,102 \mathrm{kgf}$

Assim tem-se:

$4.323,58 \mathrm{~N}$ x 0,102Kgf $=441,00 \mathrm{Kgf}$, conforme visto na Figura 35.

Cálculo preliminar: Eng ${ }^{\circ}$ Paulo Roberto Leonello 


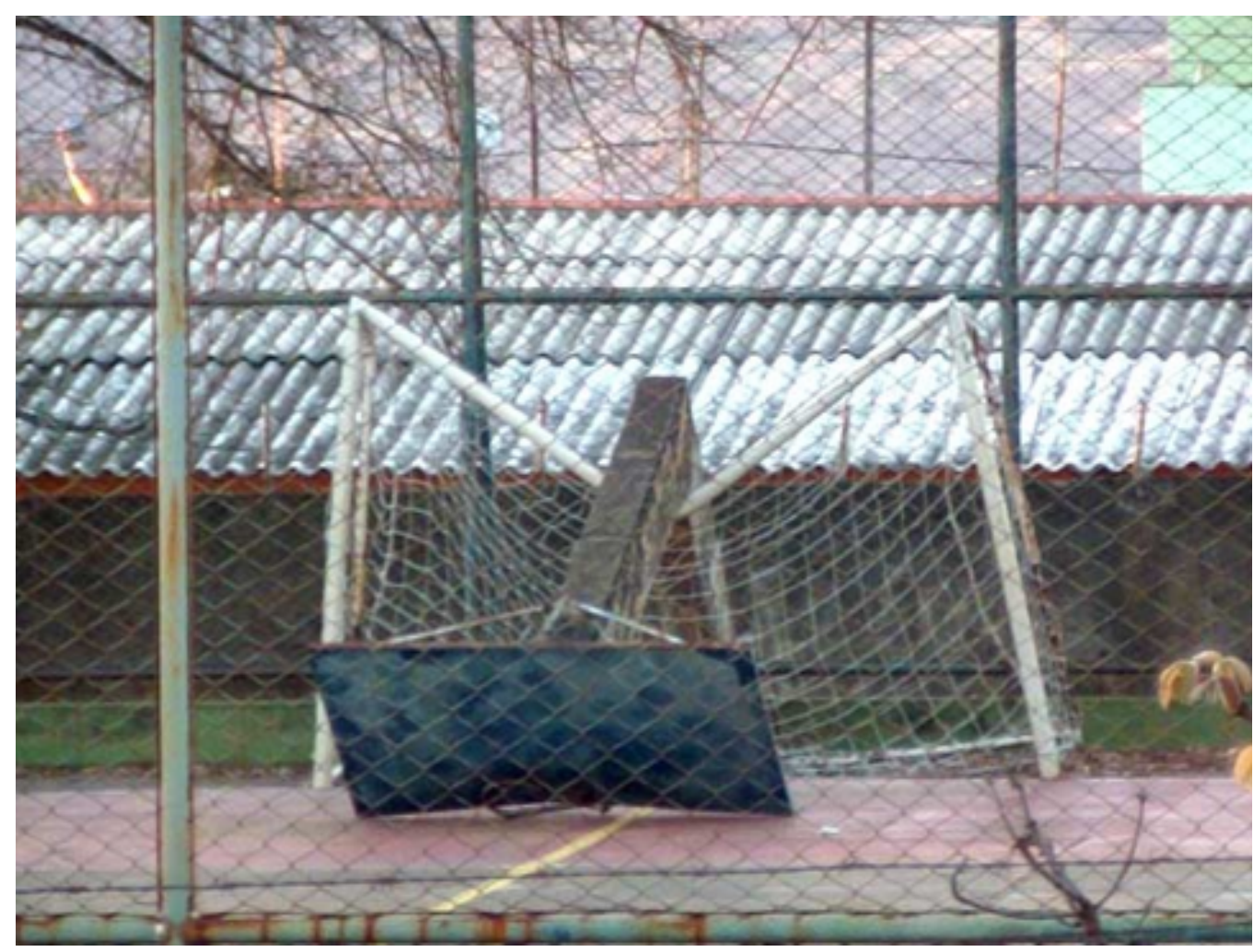

Imagem 05 - Acidente com tabela de basquetebol Tipo 7 (Poste de concreto fixo no piso). Fonte: http://g1.globo.com/distritofederal/noticia/2013/09/tabela-de-basquete-cai-e-fere-aluno-de-escola-publica-do-distrito-federal.html

$\mathrm{Na}$ inspeção predial os postes de sustentação da tabela, seja em concreto ou em aço, devem ser verificadas anualmente atendendo o Plano de Manutenção e Operação e Controle (PMOC) conforme estabelecido na norma de Inspeção Predial do IBAPE-SP, ANEXO A da NBR 14037:2014 - Diretrizes para elaboração de manuais de uso, operação e manutenção das edificações - Requisitos para elaboração e apresentação dos conteúdos da ABNT - Da Documentação técnica e legal do condomínio e norma NBR 5674:2012 Manutenção de edificações — Requisitos para o sistema de gestão de manutenção. 


\section{Revista Científica Multidisciplinar Núcleo do Conhecimento - RC: 9477 - ISSN: 2448-0959}

https://www.nucleodoconhecimento.com.br/arquitetura/instalacoes-de-traves-para-futsal-e-tabelas-de-basquetebol

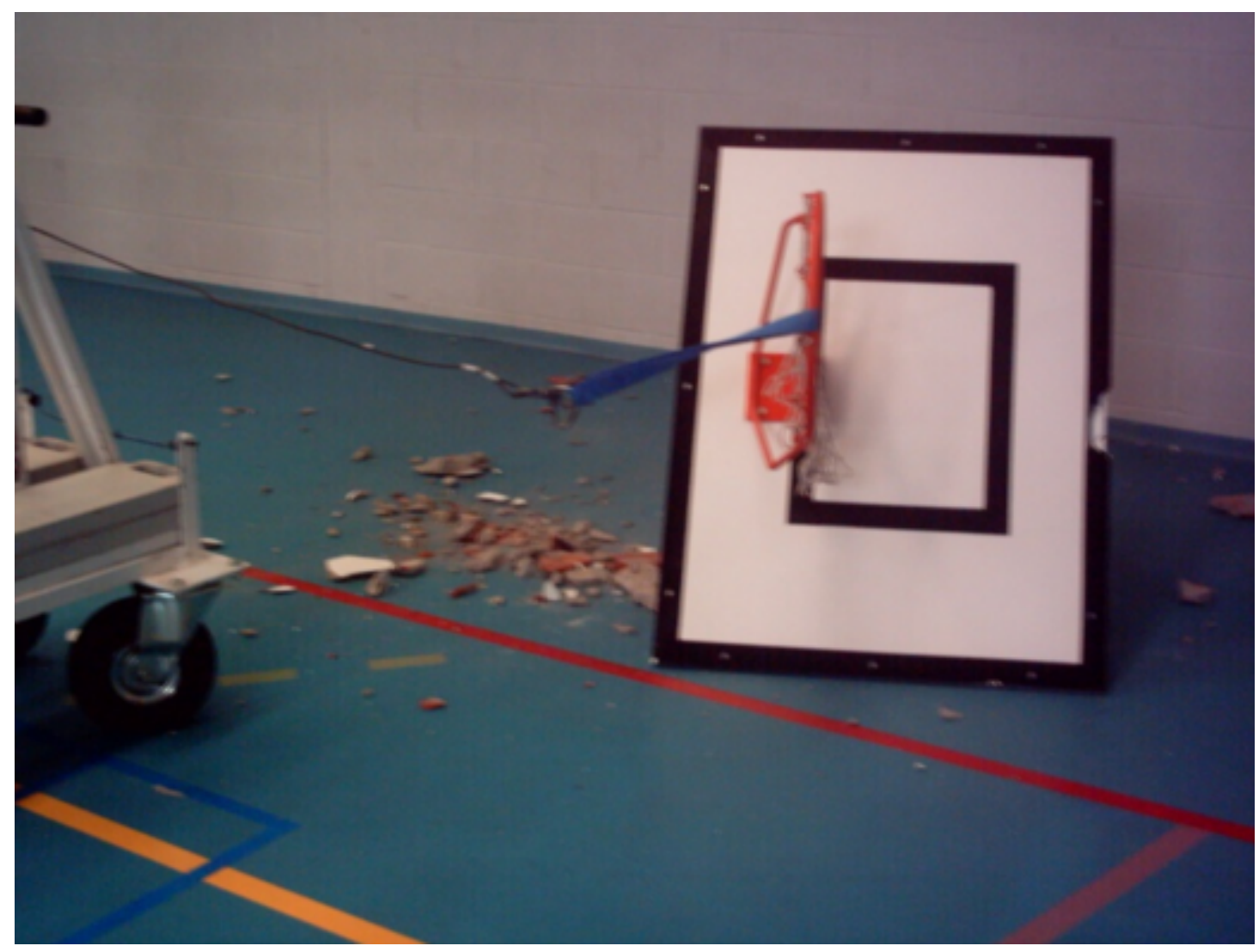

Imagem $06 \quad-$

Acidente com tabela de basquetebol Tipo 7 (Poste de concreto ou de aço). Fonte: Engo José Manuel Viegas - Lemon Safe.

Queda de tabela de basquetebol numa escola durante os ensaios de segurança, por se encontrar mal fixada.

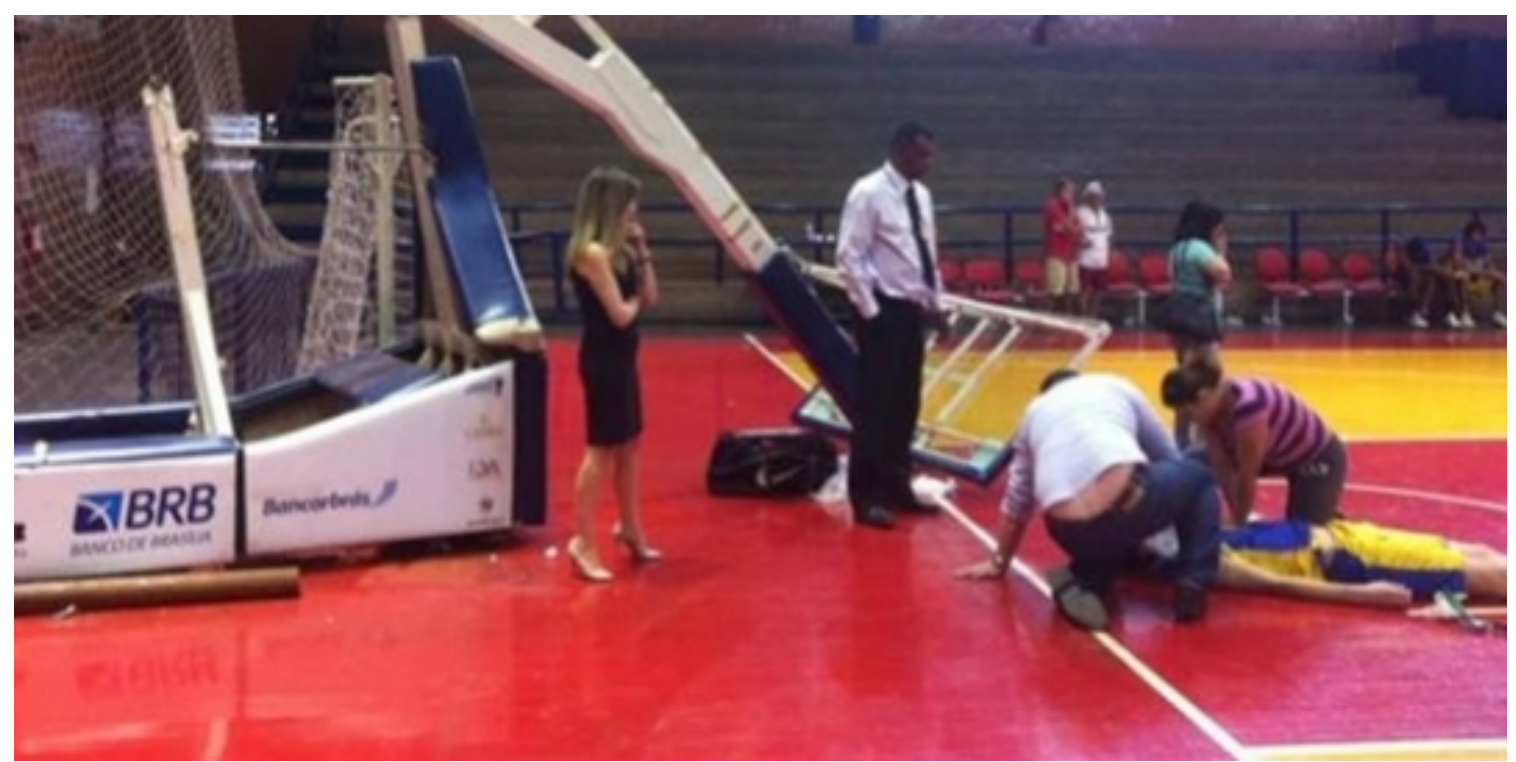

Imagem $07-$

Acidente com tabela de basquetebol Tipo 1 (Móvel ou Auto estável). Fonte: http://sportv.globo.com/site/e ventos/Taca-Brasil-de-Futsal/noticia/2011/11/jogador-do-tigre-sofre-acidente-durante-jogo-da-taca-brasilde-futsal.html 
Atleta da base do Brasília sofre acidente com tabela de basquete e é internado em estado grave, posteriormente vindo a óbito.

\section{DEFINIÇÃO DE ENSAIO PARA TABELAS DE BASQUETEBOL}

\subsection{Ensaio de estabilidade do equipamento Tipo 7 (Fixo com poste de concreto ou aço)}

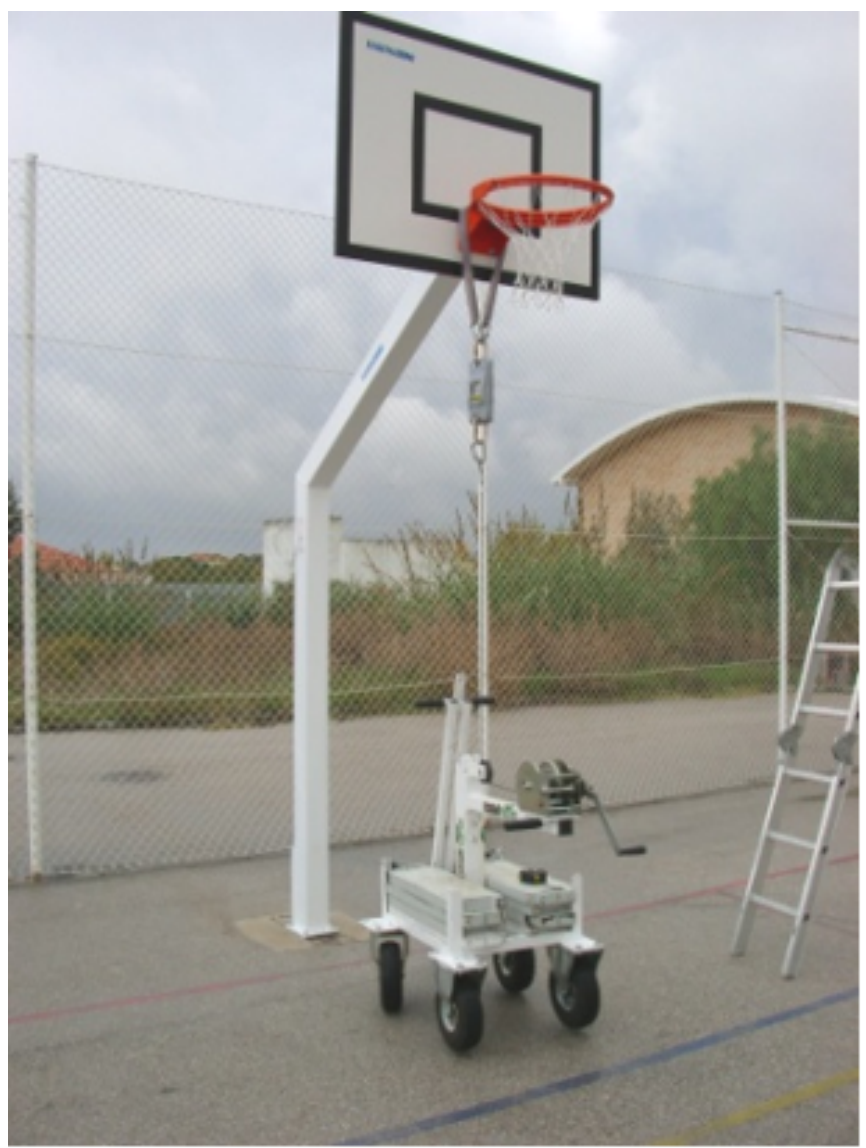

Foto 4 - Ensaio de estabilidade da estrutura do equipamento. Fonte: Eng. José Manuel Viegas - Lemnon Safe - Portugal

Deverá ser aplicada no ponto de ligação do cesto à estrutura de suporte, uma força vertical de 320 daN (326,31 Kgf) durante 60 a 70 segundos. Uma deflexão permanente será tolerada se não exceder os $10 \mathrm{~mm}$. Devem-se acrescentar aspectos a serem observados, tais como: ruídos e inspeção visual de rupturas de soldas e corrosão ao longo das estruturas.

\subsection{Ensaio de Rigidez do Aro sem Mola}




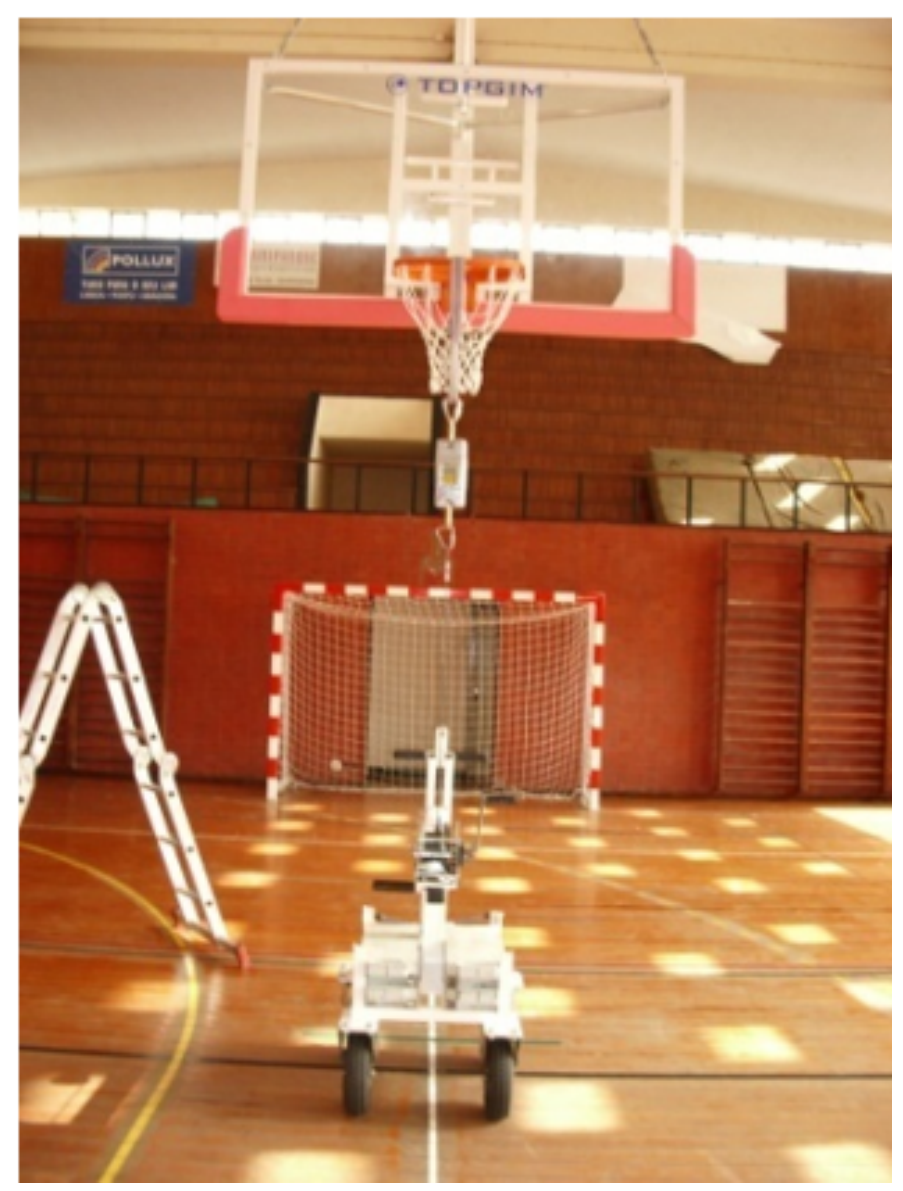

Foto 5 - Ensaio de aro com ou sem mola. Fonte:

Eng. José Manuel Viegas - Lemnon Safe - Portugal

Deverá ser aplicada ao meio do aro uma força vertical de 105 daN (107Kgf) durante 5 segundos para verificar se a mola se solta, aumentando em seguida para 240 daN (244Kgf) durante 60 a 70 segundos. Uma deflexão permanente será tolerada se não exceder os $10 \mathrm{~mm}$, sem mola apenas 240 daN durante 60 a 70 segundos. 


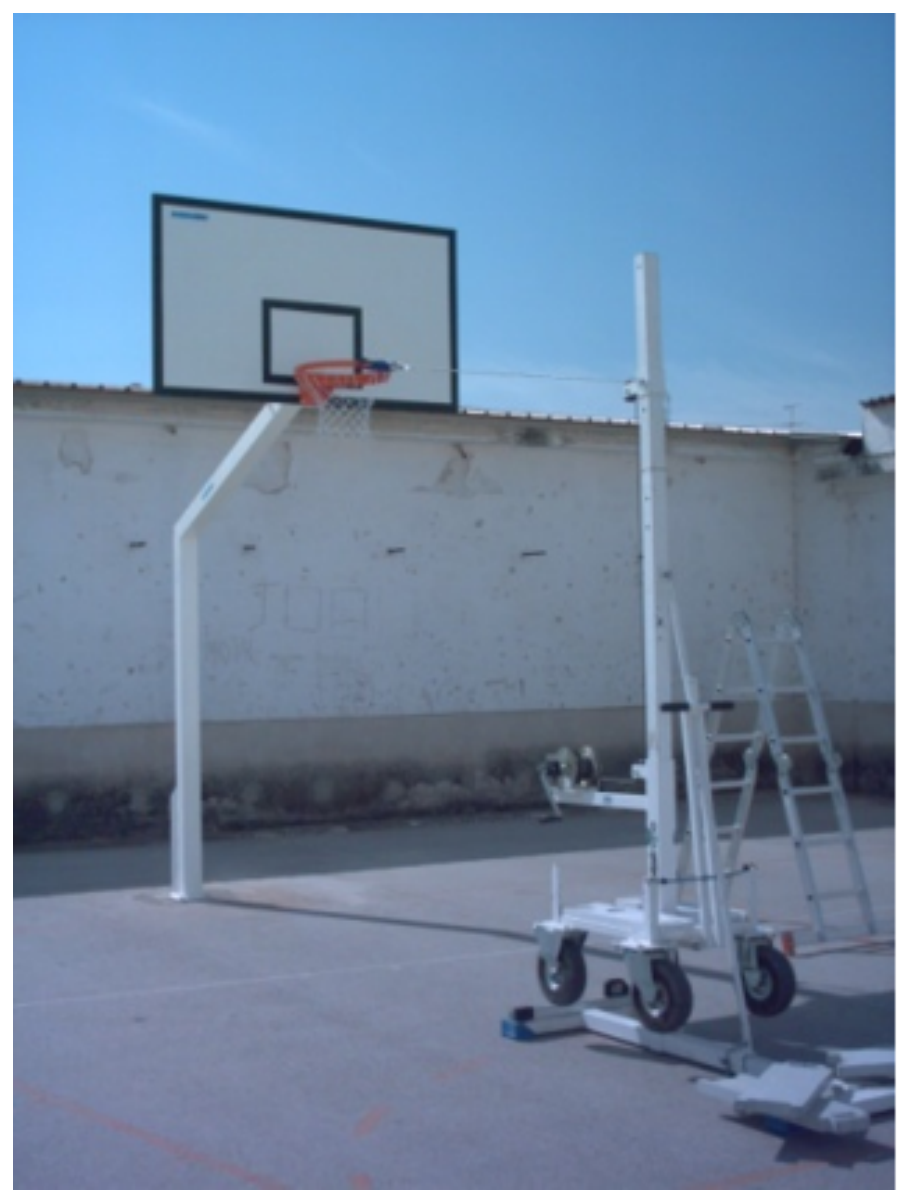

Foto 6 - Ensaio de rigidez interior/exterior. Fonte:

Eng. José Manuel Viegas - Lemnon Safe

Deverá ser aplicada ao meio do aro do cesto uma força horizontal de 90 daN, (91,77Kgf) para equipamentos instalados no interior e de $100 \mathrm{daN}(101,97 \mathrm{Kgf})$ para equipamentos no exterior, durante 60 a 70 segundos. Uma deflexão permanente será tolerada se não exceder os $10 \mathrm{~mm}$. O teste deverá ser repetido nas mesmas condições, mas aplicando lateralmente a força, no ponto de união do aro à estrutura de suporte. 


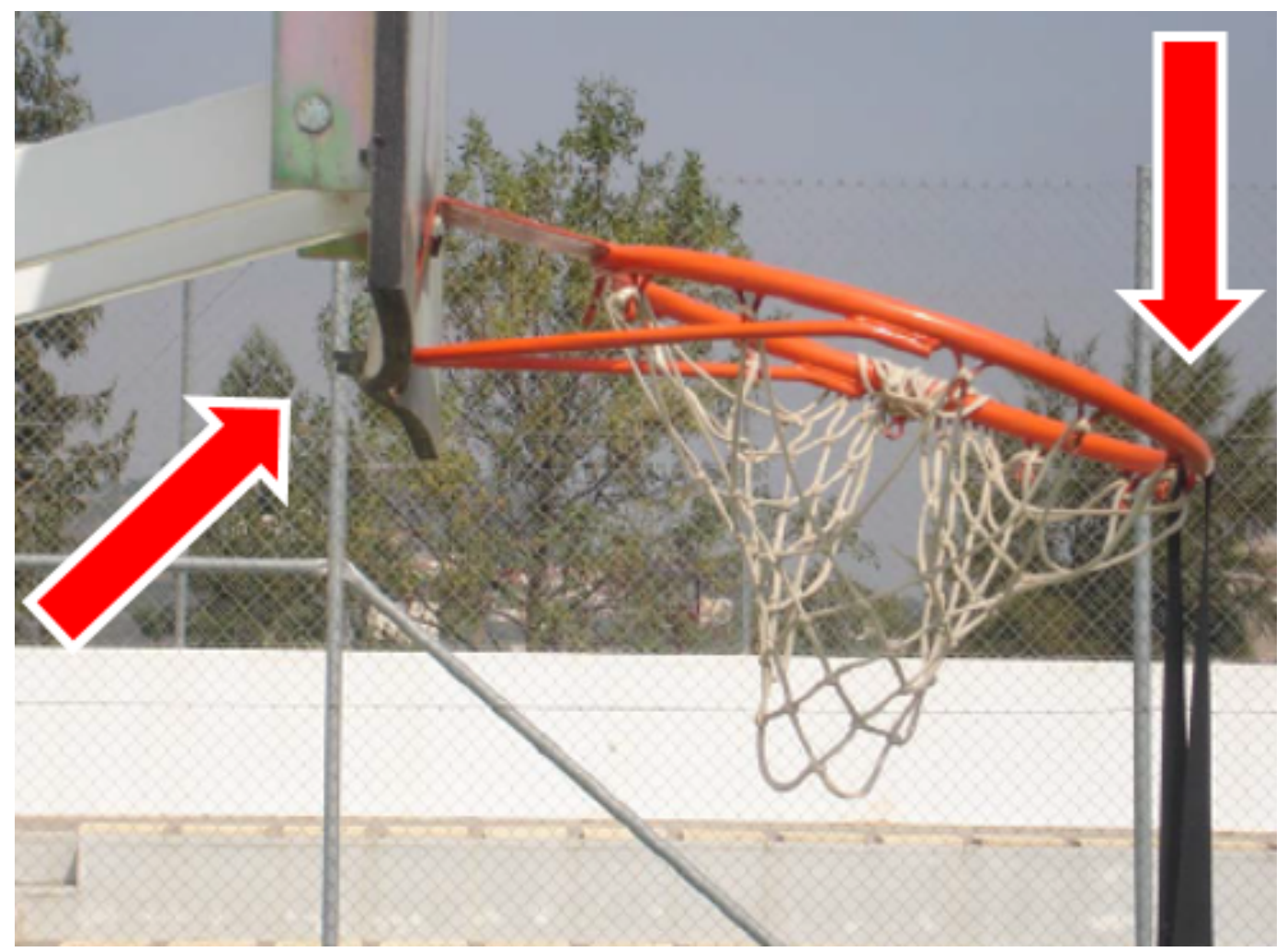

Foto 7 - Ensaio de rigidez interior/exterior. Neste ensaio percebe-se que o aro, em o painel não resistiram aos testes efetuados. Fonte: SPORT PARTNER - Distribuição e Fabrico de Equipamentos Esportivos

\section{RECOMENDAÇÕES GERAIS RELATIVAS A SEGURANÇA DE TABELAS TIPO REMOVÍVEL}

Cartazes deverão ser instalados em local apropriado com os seguintes dizeres:

\section{MANUSEAMENTO DAS TABELAS DE BASQUETEBOL:}

Para uma maior segurança as Tabelas com Carro só devem ser DESOLOCADAS com o AVANÇO totalmente RECOLHIDO

\section{REFERÊNCIAS PARA EXECUÇÃO DE TABELAS DE BASQUETEBOL}

$\mathrm{Na}$ ausência de normas técnicas brasileiras para equipamentos de basquetebol, deve-se usar como referências as seguintes publicações:

- Regulamento Liga Ouro de Basquete 2016, elaborado pela Liga Nacional de Basketball - LNB e Confederação Brasileira de Basketbal - CBB;

- FIBA - International Basketball Federation: Guide to Basketball Facilities for High-Level Competitions; Guide to Small Basketball Facilities; Guia para ginásios de basketball para competições de alto nível; Guia para pequenos ginásios para basketball;

- Equipamento de Basquetebol: requisitos funcionais e de segurança. NP EN 1270: 2006 Equipamento para campos de jogos. Portugal, 2013. 
OBS: Para situações não previstas nestas referências, prever o sistema de fixação não permanente definido neste estudo.

\section{CONCLUSÃO}

Após estudo das quadras pesquisadas chegou-se a alguns pontos críticos que levaram à necessidade de implantação das propostas de melhorias aqui estabelecidas. Não se observou, em quaisquer quadras visitadas, vistorias realizadas, tanto por parte de técnicos particulares quanto de fiscalização pública.

A falta de diretrizes normativas, ausência de normas da ABNT que tratam do tema em questão, além de informações evasivas no regulamento emitido pelas entidades do futsal e basquetebol nacional e internacional, levam a um quadro desolador de insegurança em tais recintos, principalmente os escolares.

Ressalta-se que a norma europeia NP EN 748: 2005 + Errata: 6 - 2006 - não aborda as especificações ou dimensões para trave de Futsal, que são estipuladas pela Confederação Brasileira de Futebol de Salão (CBFS) como sendo $3 \mathrm{~m}$ X 2m, sendo esta utilizada pelo autor, como referência.

A tabela do tipo "auto-estável" classificada pela International Basketball Federation (FIBA) e existente nos locais vistoriados para esta pesquisa, não apresentava nenhum sistema de segurança contra movimento pendular e eventual queda. Como todo elemento mecânico, a resistência inicial de seus elementos vai diminuindo com o tempo em decorrência dos processos de desgaste e fadiga, portanto, é necessário examiná-lo periodicamente.

Com relação aos equipamentos do Tipo-6, existentes na maioria nos locais vistoriados, são muito antigos e requerem ensaios de estabilidade da estrutura do equipamento, ensaio do aro sem mola (situação mais comum observada) e ensaio de rigidez interior e exterior, de forma a garantir a segurança dos usuários na prática deste esporte.

Buscou-se, com este estudo, definir novas regras de fixação de traves para Futebol de Salão indoor e outdoor, aqui mencionadas como "Fixação não Permanente".

No Brasil, a Norma Regulamentadora $\mathrm{n}^{\circ}$ 12, do Ministério do Trabalho e Emprego, define referências técnicas, princípios fundamentais e medidas de proteção para garantir a saúde e a integridade física dos trabalhadores que lidam com máquinas e equipamentos. Os dispositivos de segurança previstos na norma foram formalizados pelo princípio da Falha Segura. Se há uma falha técnica ou humana, o sistema entra em um estado seguro pela atuação imediata de dispositivos de segurança específicos.

Desse modo, considera-se que esta prerrogativa estabelecida pela NR12 deve ser estendida para regulamentar o uso das traves de futsal e tabelas de basquetebol, visto que os mesmos se tratam de equipamentos e devem estar sob os cuidados de um Arquiteto, Engenheiro Civil, Mecânico ou de Segurança para definir todos os detalhes construtivos e diretrizes de manutenção preventiva destes equipamentos, diminuindo a probabilidade de falhas técnicas.

No caso de escolas públicas ou privadas, o professor de Educação Física representa o trabalhador que tem, sob sua responsabilidade, os alunos que fazem uso do recinto esportivo e de seus equipamentos, bem como o supervisor, o treinador ou o técnico de equipes destas modalidades profissionais ou amadoras. 
Para o caso de condomínios, o uso das traves ou tabelas de basquetebol tem na figura do Síndico a responsabilidade pelo zelo aos equipamentos esportivos, imputando sua responsabilidade civil e criminal pelas condições seguras de uso dos mesmos.

Pela tabela abaixo, pode-se concluir que só as escolas estaduais paulistas perfazem um total de 4.754 quadras de esportes. Totalizando-se com as demais escolas em âmbito Estadual, Municipal, Federal e Particular, obtém-se o total de 12.636 quadras esportivas, que implica em 25.272 mil traves de futebol, mais 25.272 mil tabelas de basquetebol a serem inspecionadas e 12.636 quadras a serem inspecionadas, somente no Estado de São Paulo.

Tabela 1 - Educação Básica - Escolas com 8 ou Mais Classes por Tipo de Ambiente Pedagógicos segundo Rede de Ensino do Estado de São Paulo.

\begin{tabular}{|c|c|c|c|c|c|}
\hline \multirow{2}{*}{$\begin{array}{l}\text { Redes de } \\
\text { Ensino }\end{array}$} & \multirow{2}{*}{$\begin{array}{l}\text { Total de } \\
\text { Escolas }\end{array}$} & \multicolumn{4}{|c|}{ Escolas com 8 ou mais classes } \\
\hline & & $\begin{array}{c}\text { Sala de } \\
\text { professores }\end{array}$ & $\begin{array}{c}\text { Biblioteca / } \\
\text { Sala de leitura }\end{array}$ & $\begin{array}{l}\text { Quadra de } \\
\text { Esportes }\end{array}$ & $\begin{array}{c}\text { Sala de } \\
\text { Recursos de } \\
\text { Educação } \\
\text { Especial }\end{array}$ \\
\hline Estadual - SE & 5033 & 4811 & 4244 & 4602 & 972 \\
\hline Estadual-Outras & 220 & 215 & 208 & 152 & - \\
\hline Estadual & 5253 & 5026 & 4452 & 4754 & 972 \\
\hline Municipal & 8794 & 7275 & 4486 & 4341 & 2371 \\
\hline Federal & 24 & 23 & 24 & 4 & - \\
\hline Particular & 6353 & 4702 & 3763 & 3537 & 36 \\
\hline Total & 20424 & 17026 & 12725 & 12636 & 3379 \\
\hline
\end{tabular}

Fonte: Censo Escolar de 2014

Notas: SE - Escolas mantidas pela Secretaria de Estado da Educação. Outras - Conjunto de escolas estaduais mantidas e administradas pelas universidades estaduais paulistas, e pelo Centro Estadual de Educação Tecnológica "Paula Souza".

Com base no resultado do Censo Escolar de 2015, entre escolas Municipais, Estaduais, Federais e Privadas Urbanas e Rural em todo o Brasil, somam-se 183.487 escolas, das quais apenas 34\% (61.777 escolas) possuem quadras esportivas, resultando em uma estimativa de 123.554 traves e tabelas a serem vistoriadas, que provavelmente estejam em sua maioria, em condições insatisfatórias de segurança. (Fonte Censo Escolar/INEP 2014 - http://www.qedu.org.br/brasil/censo-escolar)

Observa-se neste estudo que os dados estatísticos consideraram somente as escolas, há de se ressaltar que este número se eleva ainda mais quando se consideram as quadras públicas ou particulares de clubes e as existentes em praças e parques públicos. 
Ressalta-se ainda, segundo o SECOVI-RS que em 2014 estimava-se em 186.703 mil condomínios em todo o Brasil, sendo que 58\% (107.447) deles se encontravam no Estado de São Paulo.

(Fonte: Ministério do Trabalho - RAIS 2014, CNAE 81.125 - SECOVI-RS)

\section{REFERÊNCIAS}

FEDERATION INTERNACIONALE DE BASQUEKETBALL. FIBA. Appendix to the Official Basketball Rules. Disponível em: <https://www.fiba.com>. Acesso em: 01 out. 2015.

INSTALAÇÕES E EQUIPAMENTOS DESPORTIVOS. Legislação e regulamentação. Normas técnicas. Equipamento de Futebol: requisitos funcionais e de segurança, métodos de ensaio. NP EN 748: $2005+$ Errata: 6 - 2006 - Equipamento para campos de jogos. Portugal, 2013.

Equipamento de Andebol e Futsal (Traves): requisitos funcionais e de segurança, métodos de ensaio. NP EN 749: 2005 + Errata: 6 - 2006 - Equipamento p/ campos de jogos. Portugal, 2013.

Equipamento de Basquetebol: requisitos funcionais e de segurança. NP EN 1270: 2006 Equipamento para campos de jogos. Portugal, 2013.

SOUZA, Paulo José de. TIBEAU, Cynthia. Acidentes e primeiros socorros na Educação Física escolar. Disponível em <http://www.efdeportes.com/efd127/acidentes-e-primeiros-socorros-na-educacaofisica-escolar.htm>. Acesso em: 15 out. 2015.

[1] Arquiteto e Urbanista, graduado pela Universidade Mogi das Cruzes (UMC) em 1991; Designer Industrial pela Faculdade de Desenho Industrial de Mauá em 1986; especialização lato sensu em Engenharia Civil, Especialista em Tecnologia da Construção pela Universidade Sociedade Educacional de Santa Catarina; Membro Titular do Instituto Brasileiro de Avaliações e Perícias de Engenharia de São Paulo desde 2003; sócio proprietário da Chervenko Engenharia Ltda. desde 1992.

\section{PUBLIQUE SEU ARTIGO CIENTÍFICO EM:}

https://www.nucleodoconhecimento.com.br/enviar-artigo-cientifico-para-submissao 